\title{
Existe um pensamento político brasileiro?
}

\author{
Raymundo Faoro
}

\section{Do Pensamento Político}

\section{Existe um pensamento politico brasileiro?}

A pergunta envolve duas proposições o pensamento político e uma especificidade, o pensamento político brastleiro. Se há um pensamento polítıco brasileiro, há um quadro cultural autonomo, moldado sobre uma realıdade social capaz de gerá-lo ou de com ele se soldar. Nesta parte, é oportuna a reflexão, dentro de farta bıblıografia, da ımıtação, da cópia, da ımportação de paradıgmas e modelos culturaıs. A primeıra proposição, pertinente ao pensamento político, extrema o pensamento, o pensamento caracterizadamente político, da ideologia e da filosofia polítıca, entendıda nesta locução também a ciència política, mais por motivos de conveniência do que de rigor conceitual. Para não descer às origens, o ponto de partıda é o pensamento, sem voltar ao debate socrático acerca do conhecer e do saber, como está no Teeteto (PLATÃO, p. 88 - segs.)*. Pensamento, dıga-se em redução dicionarızada e simples, é o que se tem em mente. quando se reflete com o propósito de conhecer algo, de entender alguma coisa e quando se delibera com o fim de tomar uma decısão. O pensamento, como ato de pensar, é uma atividade que se dirige ao objeto e cogita de apreendê-lo. Var-se a definıção, ainda que exposta a retıfıcaçōes, sempre provisória.

O pensamento polítıco não é conversivel à filosofia polítıca, à ciêncıa polítıca ou à ideologia. Pode haver - e frequentemente há - pensamento polítıco que não é ideologia e que não é crência e filosofia polítıca. $\mathrm{O}$ pensamento político se expressa, quase sempre, em uma ou outra manifestação: como 1deologia e como filosofia ou ciência política. Ele tem, entretanto, autonomia. É o que se tentará demonstrar, para o efeito de caracterizar-lhe a estrutura, na sua dımensão atuante e autônoma.

A filosofia política e sua enteada, a clència política, não nascem do mesmo parto. O pensamento político é a polítıca, não a construção da política. "A filosofia politica - lembra Leo Strauss - não se identifica ao pensamento politico. $O$ pensamento politico é coevo à vida politica. $A$ filosofia politica, entretanto, emergiu de uma vida política especifica, na Grécia, em passado que deixou registros escritos. De acordo com a visão tradicional, o ateniense Sócrates (469-399 a.C.) foi o fundador da filosofia politica. Sócrates foi o mestre de Platão, este, o mestre de Aristóteles. As obras politicas de Platōo e Aristóteles são as obras mais antigas dedicadas à filosofia politica que chegaram até nós" (STRAUSS e CROPSEY, 1973, p. 1-2).

$O$ legado socrátıco, na versão platônıca, traduz o encontro entre filosofia politica e polítıca, numa encruzilhada dramátıca da humanidade, com a crise da polis grega. $\mathrm{O}$ acento dramático fica por conta da idéia de que o mundo político seria moldável pela arte humana, de sorte a entregar o poder político ao filósofo (WOLIN, 1960, p. 34). Nesta identificação entre filosofia e política está a base do construtivismo, que frequenta a política ocidental em muitos momentos e em muitas direções. Trata-se de uma identificação que, na realidade, oculta o predomínio do logos sobre a práxis, em modelo sempre referencrável

\footnotetext{
* Observe-se que as referências bibliográficas, a seguir, nāo indicam adesāo ao autor citado, senão que o assunto foi por ele versado, embora em outros termos e com diferente sentido.
} 
no voluntarismo, no denunciado despotismo das influências das teonas sobre os fatos, na importação de valores e programas. Entre o pensamento politico e a filosofia polítıca, não haverıa espaço em branco, coberto o eventual antagonısmo com os filósofos no poder. Ganha dimensão, no esquema, o elemento construtor, arquitetônıco da polítıca. $\mathrm{O}$ magistrado - dita o paradigma - seria 1gual ao cego se, como o pintor, não reproduzisse na tela o modelo, expresso na justıça (La républıque, Pléiade, v. I, p. 1063) "Se o estadista for ignorante do fim a que visa, seria válido, em primeiro lugar, dar-lhe o nome de magistrado, $e$, em segundo lugar, como poderia ele salvaguardar o fim que não conhece?" Ausente da filosofia, quem serı o detentor do poder, senão o imprevidente oportunista" "Não seria surpreendente que, vazio de inteligência e de sensibilldade, se entregasse, caso a caso, ao fortunto da primeira coisa que ocorresse?" (La république, Les lors, t. II, p. 1119).

A redução do pensamento polítıco à filosofia política leva a desfigurar a polítıca e a converter a histórıa à histórıa das idéras. Toda uma categona social se perderıa. A Revolução Francesa terıa nascido - para levar a tese à carıcatura dos filósofos. $\mathrm{O}$ mundo soviético teria sua origem no Manifesto Comunista, depois de quase um século de maturação. A política se desvincularia da realidade, perdida numa teia de doutrinas e de 1désas, em simplismo que a tornaria o desvario de cérebros ociosos. Não faltam precedentes a essa mistificação literárıa a que, por exemplo, pintou a Revolução Francesa como a quimera póstuma de Rousseau. Esta não é a tese de Tocqueville, que soube distingurr o pensamento político da filosofia polítıca, o intelectual, com suas fórmulas, da idéra que ganha a sociedade e, por 1sso, adquire o contorno de uma força soc1al (TOCQUEVILLE, 1952, t. II, p. 193 - segs.). Ele soube identıficar, nesse passo, o espetáculo ıdeológico, ao mostrar a França divıdıda em doıs planos num corrı a adminıstração, noutro floresciam os princípios abstratos.

"Acima da sociedade real, cuja constituição era ainda confusa e irregular, onde as lets permaneciam divergentes e contraditórias, as hierarquias estanques, fixas as condıçôes e desiguais os encargos. construia-se, pouco a pouco, uma socledade imaginária, na qual tudo parecta simples e coordenado, uniforme, equitativo $e$ conforma à razão "(TOCQUEVILLE, 1952, t II, p. 199.)

$\mathrm{O}$ pensamento polítıco atua, deformando-se, na ideologia. No estado puro, as ıdéias e representações produzıdas pela consciência expressam dıretamente a "atıvidade material $e o$ comércio material dos homens, como a linguagem da vida real. As representações, os pensamentos, o comércio espiritual dos homens se apresentam, nessas curcunstâncias, como emanação direta de seu comportamento material" (MARX

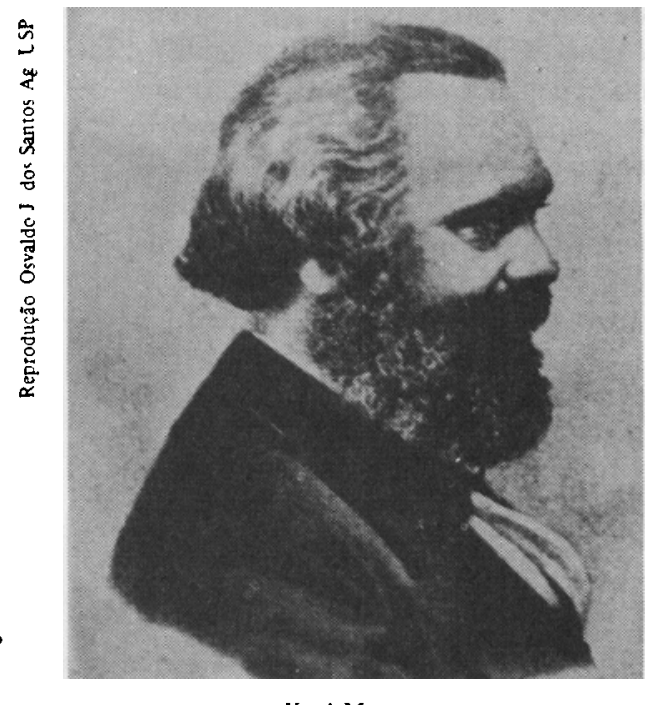

Karl Marx
(. . .) atividade material e o comércio material dos homens, como a linguagem da vida real. As representações, os pensamentos, 0 comércio espiritual dos homens se apresentam, nessas circunstâncias, como emanação direta de seu comportamento material. 
e ENGELS. 1959, p. 25). A politica, o diresto, as leis traduzem o "processo de lida real" dos homens. Os fazendeiros de São Paulo, comc os surpreendeu Saint Hillaire, às vésperas da Independência, tipificam o compnrtamento não-1deológıco: "mostram-se - dizo viajante - absolutamente alheios às nossas teorias (. . .) a única coisa que compreendem é que o restabelecimento do sistema colonial lhes causaria dano porque se os portugueses fossem os únicos compradores de seu açúcar e café não mais l'enderiam suas mercadorias tão caro como agora o fazem " (SAINT HILLAIRE, 1938, v. 126, p. 167). O sistema colonial sofre, para os rudes lavradores, a objeção de seus interesses, nuamente expostos, sem apelo às doutrınas lıberais. Estes não crıam, pela via ideológica, o imagınário que lhes universalıze os interesses, nem o recobrem do véu que os deforma. Não entra cm cena a câmara escura, na metáfora famosa, que inverte as relações, insınuando o domínio das idéias e não das relaçōes reaıs e concretas. A ideologıa, além desse papel de dissımuladorá, opera como meio de hegemonia polítıca, numa classe que se pretende representar a sociedade global. Por meıo dela, com a intermedıação dos intelectuars, como na instância a que se aludiu, no camınho da Revolução Francesa, cımentam-se as homogeneidades e organiza-se a luta social. Ela constitui o terreno "sobre o qual os homens se movimentam, lutam, adquirem consciência de sua posição" (GRAMSCI, 1966, p. 62-3). As idéias da classe dominante tornam-se, pela operação ideológica, capazes de solidificar o núcleo de comando e de satelizar as classes subalternas aos interesses dominantes. "Em outras palavras: a classe que exerce o poder material dominante na sociedade $\dot{e}$, ao mesmo tempo, seu poder espiritual dominante" (MARX e ENGELS, 1959, p. 48-9).
Trata-se de um pensamento formulado, que, numa estrutura coerente, explica o contágio das ideologias, que transitam com independência das condições reais $e$ substantivas para outro espaço. As ideologias por contágio revelam uma incongruência social e histónca, tal a dos "teutöes pelo sangue e liberais pela reflexẫo", condenando os atores a pensar "em politica o que outros povos fizeram" (MARX, 1968, p. 14, 29-30).

A ideologia comporta outro perfil, corrente no vocabulário político. No paradigma marxista, a consciência ıdeológica é uma "ilusória" e uma "falsa consciência" (LUKÁCS, 1960, p. 90). Uma classe, cujo domínı polítıco é exercido por uma minoria, no interesse dessa minoria, difunde-se, para que outras classes se Iludam, confundindo-se na sua verdadeıra consciência de classe. Os ideólogos dominantes lutam para que se oculte a essência da própria classe, unıversalızando-a em conceitos abstratos, ao mesmo tempo que nega a autonomia dos interesses das outras classes. A consciência ılusória, ao se duplıcar na falsa consciência, "cobre a realidade e a revela, deformando- $a$ ": representa a figura de véu e de máscara (BOBBIO, 1977, p. 113). Em outro sentıdo, mass comum na lınguagem, a ideologia significa genericamente um "sistema de crenças ou de valores, utilizado na luta politica para influir sobre o comportamento das massas, para orientá-las numa direçāo $e$ não em outra, para dirigir o consenso, para justificar o poder" (Idem, p. 114). Não alude, no caso, à função mistificante: representa o papel de um programa de um movimento político. É a ideologia em sentido débil, para distingui-la do modelo marxista. Trata-se de uma forma de pensamento político em batalha, com uma característica que a diferencia do pensamento político em estado puro. A ideologia em sentido débil exacerba, embora não-mistificante 
por definição, um elemento do pensamento político, o elemento da ação. $A$ eficácia da idéia assume a importância maior, com desprezo, embora involuntário, da pauta de verdade.

A ideologia, como ação desvinculada do compromisso com a verdade, é interessada unicamente na eficácia, e a ideologia, que organiza o consenso hegemônico na sociedade civil, reina no território da práxis. Cercada num raciocínio circular, tudo seria ideologia: uma ideologia substitui outra, ainda que criticamente. No outro extremo, a filosofia política reduz o pensamento político ao logos, em proposições científicas ou filosóficas: a realidade seria o espelho da teoria. Ambas, a filosofia política e a ideologia (nos dois sentidos), sistematizam, formulam, estruturam a política. Fora delas, se aceitas suas premissas, haveria apenas a política alheıa à congruência - espécie de política irracional -, a política cujo segredo é não ter política, aquela que lord Acton atribuía a lord Liverpool. A política cujo segredo é não ter política é uma pobre e insustentável falácia, falácia cuja astúcia estaria no ocultamento do jogo - o mais refinado de todos. Ela, a política que não é filosofia, nem ciência, nem ideologia, que não se extrema na ação, nem se racionaliza na teoria, ocupa, na verdade, o espaço do que se chama pensamento político, não necessariamente formulável, não correntemente racionalizado em fórmulas. "A glória de mandar, amarga e bela", seria seu campo - o campo da atividade. Os fins estão no resultado, naquilo que Weber qualificou de ética da responsabilidade, responsabilidade no sentido de resposta da ação, no intercâmbio de ações, posta em segundo plano a intencionalidade da conduta.

Esse pensamento é o pensamento político em estado puro para efeito de definição teórica. Ele atua como saber informulado (OAKESHOTT, 1984, p. 83 - segs.).

0 pensamento polítıco não será o residuo, nem a escória das ideologias, nem a política em estado de modelo, composto de proposições enunciativas, que denotam em que consiste um ser ou um valor, o que na realidade é, como existiram os fenômenos e como se desenvolveram (SICHES, 1965, p. 116). Sua natureza compatibiliza-se com o saber informulado, que não se confunde com a irracionalidade, nem com o oportunismo. Ele não cuida da transmissão, mas da ação, numa práxis que se desenvolve no logos. Suas prescrnçōes são normativas, localizam-se no mundo da práxis, pelo que atuam fora da lógica proposicional. Sua função é a de direcionar a conduta humana em determinado sentıdo, não de representá-la enuncrativamente, descritivamente. As suas proposições, embora mensuráveis pelo critério da verdade, cuidam da valıdade, como convém ao mundo da práxis (PINTO NEVES, 1985, p. 5-6). Suas proposições assumem o significado dos sistemas nomoempiricos, tal como as normas do direito. "O caráter nomoempirico distingue-o dos sistemas nomológicos (lógicos e matemáticos), pois são-lhe relevantes os dados $d a$ experiência. A sua função prescritiva (normativa, incluindo-o na ordem da práxis, diferencia-o dos sistemas nomoempiricos teoréticos (descritivos), insertos na ordem da gnose. Isto porque, ao contrário dos sistemas nomoempíricos descritivos, o ordenamento juridico (leia-se o ordenamento do pensamento politico) é näo apenas aberto aos dados da experiência e por eles condicionado, mas exerce também a função principal de controlá-los e dirigi-los diretamente." (PINTO NEVES, 1985, p. 22.)

$\mathrm{O}$ iter do ato político, segundo o modelo e o preconceito do 
nomoempírico, marcado pelo preconceito intelectualista, se faria em três lances.

Concentra-se na idéia do pensamento político como atividade que se tem em mente, não como práxis. Em primeiro lugar, haveria a proposiçâo, enunciativa na sua consistência, premeditada, que levaria, por estímulo interno, à açâo. Em seguida, escollher-se-iam os meios, com os quais, em terceiro momento, se constituiria o resultado exterior. No esquema, perde-se a base real do pensamento, o estímulo ex terno. $O$ saber seria, ainda implicitamente, o saber formulado, dedutivel em proposições. $O$ logos, como saber formulado, organizado em proposiçōes, antecede e domina a práxis, que é um saber informulado, embora não-esotérico, nem informulável - mas formulável $a$ posteriori, a partir da ação. Os eventos políticos seriam um reflexo da idéia: no princíp1o, o verbo se faz ação. Em simplificação não-ınédıta: o Contrato Social determinou a Revolução Francesa, a Declaraçāo de Independência, com seus princípios estruturados, culmınaram na Independência Norte-Americana. A históna do pensamento político seria a arena das idéias, num confronto de paradigmas abstratos, vencendo uns no imperativo de sua coerência e energia internas. Sequer no território da ciência

A história do pensamento político seria a arena das idéias, num confronto de paradigmas abstratos, vencendo uns no imperativo de sua coerência e energia internas. Sequer no território da ciência pura teria pertinência o modelo: $o$ fato cientifico e a teoria não são categorias separáveis. pura teria pertinência o modelo: $o$ fato científico e a teoria năo são categorias separáveis. Uma e outra são amalgamadas por uma ordem social - a comunidade científica - que decide pela vigência das revoluções do pensamento. $O$ acento que explica as revoluções científicas encontra seu ponto de apoio na função normativa e não na função nomoempírica (ou cognitiva). A recepção do conhecimento novo se dá dentro de uma crise, que não é uma crise intelectual, mas uma crise que determina a recepção do fato novo (KUHN, 1983, p. 25, 155, 199). Na verdade, outro é o roteiro do pensamento político: ele não atua pela energia interna, impelido pela verdade ou pela justiça, mas, sem abandono da justiça e da verdade, pela probabilidade de ser incorporado à ação.

O logos - a filosofia política, a ciência política, as ideologias - transita, pode ser exportado e catalogado, comunica-se, frequenta os livros e os discursos.

Expressa-se em proposições enunciativas, escrito nos livros e nos discursos: é um saber formulado. $O$ pensamento politico, entretanto, como ação, como atividade concentrada, não se confunde com o exercicio de jornadas intelectuais, como exercicio retórico. A ideologia e a filosofia política corporificam um princípio politico e se propõem a realizá-lo. A liberdade, a igualdade, a democracia, o Liberalismo seriam alguns exemplos desse padrão. Designam o que se persegue independentemente de como fazê-lo. Na verdade, $o$ pensamento político não se desenvolve com base na premeditação dos principios, mas na consideração sobre o campo da própria politica. Em suma: a atividade política vem antes, precedendo as formas do logos. O pensamento político é, assim, um ato político, compreensível politicamente, não em pautas abstratas. Não há a possibılıdade de fazer a política, desenvolvendo o pensamento político, segundo um manual, como não se faz um cozinheiro com um livro de cozinha (OAKESHOTT, 1984, p. 83 - segs.). 0 logos político é, desta forma, não o prefácio, mas o pós-escrito da atividade política, como experiência. Para que o princípı,o, o instituto jurídico, o meio de realização atuem, é necessário que eles sejam mais do que a fórmula, o princípio, o premeditado fim perdido no logos. Eles devem radicar-se na sugestão, na indireta intimação (intimated) de uma maneira concreta de conduta (Idem, p. 10, 121). $O$ pensamento politico está dentro da experiência política, incorporado à ação, fixando-se em muitas abreviaturas, em 
corpos teóricos, em instituiçōes e leis. A ıdéıa, por essa vıa, faz-se atıvidade, não porque fruto da fantasia ou da ımaginação, mas porque escolhıda, adotada, incorporada à atıvidade polítıca. $O$ vinculo entre a práxis e o logos se dá pela sugerência, palavra que, em falta de melhor, indica o modo como se expressa o quantum possível de saber formulado a partır da experiência. $O$ poder da sugerêncıa ultrapassa a compatıbilıdade lógica que se expressa no pensamento polítıco. A própria leı, ainda que coercitivamente dotada de podèr, terá eficácia cırcunscrita às situações de força se despıda de sugerêncıa. $O$ preconceito racial, por exemplo, se representa um traço do pensamento polítıco, obstınar-se-á em se manter, anda que as sanções penass o repudiem. Uma leı não se completa por outra lei aında maıs severa na sanção ou maıs dúctıl: sua valıdade $e$, complementarmente, sua eficácia, dependem de como atue na prảxıs e não no catálogo das normas obriga tónas.

O saber informulado - pela via da experiência, a que está na sugerència é o registro de entrada no saber formulado, canal seletivo e inıbitónio. A escolha, a determinação do pensamento polítıco é uma atıvıdade, uma ação política. $O$ pensamento político de cada um não se afirma na fórmula intelectual, mas na atıvıdade real, implícıta na ação, ainda que, à margem desta, afirme-se outra idéia. A eventual contradıção entre a regra e a conduta rompe-se privilegiando a conduta: nela está o pensamento político real, embora a contradıção intelectual nada tenha a ver com a má-fé. A verdadeıra ação, a da sociedade e de cada um, contém-se na política (GRAMSCI, 1966, p. 14.5). A consciência teórica da ação é irrelevante, mas equivoco seria consumi-la numa fórmula.

O saber informulado, que, pela via da práxis, compð̃e o pensamento polítıco, está na sugerência; é esta que o dıstıngue da fantasia, do arbítrıo imaginativo e da 1deologia. A sugerência, em direções contrárias, freia, de um lado, o desenvolvimento teórico, dando-lhe consistência prátıca, e, de outro, marca o lımite da presença da sociedadc. Os estilıstas vitorianos da modá, lembra um ensaísta já e largamente mencionado, propuseram-se criar, para as ciclistas, um traje adequado à bicicleta. Se o processo de criação fosse livre e coerente, obediente só à lógica, terıam desenhado o short. De um ponto estritamente técnico e intelectual, eles fracassaram, ao vesturem-nas com o bloomer, pouco funcional à bicicleta, mas conveniente an recato das castas vitorianas. Os costureiros obedeciam, ainda que inovador o pensamento, aos limites sociass que a sugerência lhes inspırou. Em lugar de um escândalo, lançaram a moda nos ousados lımıtes da criação.

A província da práxts, em que atua o pensamento político, forma-se e ordena-se por meio de idélas abstratas e sıstematızáveis. A prátıca é uma atıvıdade. mas esta atıvidade polítıca não será nunca a polítıca cujo segredo é não ter polítıca

Toda sua carga de vontade não a afasta das idéıas. A prática - a práxis reencontra-se com a razâa prátıca, com a tradıção normatıva da étıca e do dıreıto, desde Arıstóteles "O mundo da experiência prática é um mundo de juizos, não de meras açōes, volıções, sentimentos, intuições, instintos ou opiniōes $A$ verdade prática é a coerência do mundo da experiência prática." (OAKESHOTT, 1978, p. 258.)

O pensamento político é uma atıvıdade a atıvidade é o territóno da prátıca. A atıvidade é e ainda não é. " $A$ atividade envolve uma discrepância entre o que é e o que desejamos que venha a ser."(Idem, p. 257.) 
Há, na atıvıdade e, a fortiori, na prátıca, o trânsıto entre formas e estruturas de exıstêncıa, em dupla perspectiva. De um lado, no territóno do ser, de outro lado, no campo do valor. O que é virá a ser, mas virá a ser de acordo com valores: o direito. a justıça, lımıtados o ser e o valor pela sugerência. Esta dımensão vıncula a prátıca à experiência, ao saber informulado e à realıdade. A realıdade polítıca não exıste fora da experiencia, salvo nas pıojeçōes epistemológıcas do realısmo ingênuo. A prátıca polítıca descende, portanto, da étıca, mas não é a ética, embora ambas partıcıpem da razão prátıca. A ativıddde que está no pensamento polítıco partıcıpa do campo do ser, sem que seja mero valor: é o ser que se desenvolve num mundo de valores.

O pensamento polítıco está sob a jurısdição da práxis. A práxis, entretanto, não é um feıxe caótıco de ınstıntos, mas de ıdéias. A recuperação do pensamento político, com seu isolamento conceitual, o extremo da falsa consciência, do mito e do arbítrio teónico. Por esse meı se revitalıza a realıdade polítıca, não a mítıca realıdade nacional, o velocino de ouro do reducionismo, que a procura na subtração das camadas de tınta estrangerras que a recobriram (SCHWARTZ, 1977, p. 14 - segs.)

Realıdade tem o sentıdo de dınâmica, de atıvidade, que, ao se desenvolver, revela a estrutura social, "fazendo a opressão mais opressiva, acrescentando-lhe a consciência da opressão" (MARX, 1968, p. 17). $O$ pensamento político, porque atıvidade, contém carga crítica, que não se confunde com a escolástica, nem participa da visão teórıco-contemplativa. Como valor e como o ser que virá-a-ser, corrosivo da 1deologia e do imobilismo da filosofia política. Acompanha e potencializa a dialétıca social, à qual se vincula, sem ser mero reflexo, por meio de manifestaçð̃es múltiplas, que não estão necessarramente submersas no saber formulado, com o rótulo polítıco. Em certos momentos, o pensamento político se expressa melhor na novela do que no discurso político, mass na poesia do que no panfle to de circunstâncıa. Repele as especıalızaçōes, expandındo-se em todas as manıfestações culturats, ainda que se afirme o congelamento Idcológıco e o enciclopedısmo filosófico.

\section{A Revolução Irrealizada}

Una icvolução c uma dinastıa nova, Aljubariota c Avis (1385). Inauguram, precocemente, a época moderna em Portugal. Uma revolução popular e burguesa - celebrada como se fosse uma revolução democrátıca (CORTESÃO, 1964, p. 225) - assegura a vitóna de uma política nacional, $a$ polittca do transporte contra a política da fixação (SÉRGIO, 1972, p. 27). A politıca marítıma. centrada na navegação e nos portos, sustentada pela burguesia comerćlal, é o germe da descoberta do globo c da expansão do mercado. Burguesia comercial, que nunca conseguiu transıtar para a criação manufatureıra, desvinculada da produção agrícola, incapaz, por isso, de uma duradoura e unıversal mudança cultural.

Todos os bens de exportação eram obtıdos fora de Portugal, na cldade-feira de Flandres. $\mathrm{O}$ artesanato decal, a agricultura degrada-se. Em compensação, vitoriosos, os descobrimentos acentuam o poder central, no absolutismo prematuro, enriquecido com o ouro da África e as especianas da Ásia. A Coroa seria a dispensadora de todos os bens, atraindo na Corte as energias rurais, com os fidalgos pedintes, "para sugarem ao rei o prcduto da exportaçāo comercial, em tenças, morgadios, reguengos, jurisdições, - de maneira que (diz um escritor do século XVI) mais parecia ser 
pai, ou almoxarife, que rei, nem senhor" (SÉRGIO, 1972, p. 95). Apesar da fenda que existia no edifício, o papel do reino, com seus enormes encargos, exıgia profunda adequação intelectual aos fins propostos. Uma aproxımação com a Europa, nas primerras luzes do Renascimento, seria o meio natural do universalısmo geográfico e da necessidade de estruturar conhecimentos novos, próprios às descobertas. As oficınas tıpográficas prolıferam a partir de 1536 . 0 ensino prospera à margem da Universidade: "deixa de ser concebido como uma preparação especializada para a clericatura ou para a administração, realizada através da Universidade. Surge um esboço de ensino elementar (ler, escrever e contar) e escolas de cultura geral para a nobreza e para a burguesia. São os humanistas que estabelecem os programas para estas escolas. $\boldsymbol{A}$ Universidade medieval permanece inalterada no seu conjunto, mas $v \hat{e}$ reduzir-se a sua influência, concorrida pelas novas institutções" (SARAIVA e LOPES, 1968, p. 150). O Humanismo português, como tudo, prospera com o aporo da Coroa. D. Manuel (m. 1521) e D. João III (m. 1557) pensionaram estudantes para estudar no estrangeiro. Tudo isso enquanto não vem a Contra-reforma, com o Concílıo de Trento (1545). Havia uma necessidade decorrente dos próprios descobrimentos de reformar a cultura portuguesa, que estará na base do pensamento politico.

\footnotetext{
"Os descobridores - escreve Antónı

Sérgio - recorriam constantemente, nos seus trabalhos, aos geógrafose naturalistas da Antiguidade, que eles conheciam minuciosamente; ora, a visão assidua dos espetáculos novos, da realidade exótica, mostrava-lhes a cada instante os erros enormes desses autores, a cujas afirmaçōes se prestara fé como a revelações do próprio Deus. Ao tratar-se de coisas de nossos climas (coisas
}

familiares, por isso, ao espirito de seus autores), eram os textos da Antiguidade suficlentemente verdadeiros; ao descreverem, porém, os produtos ultramarinos, os erros dos textos acumulavam-se, imediatamente verificáveis para quem pudesse conhecer as cotsas por sua direta observação. "Esta v1são da realıdade exótıca tınham-na os portugueses nas navegaçōes: notaram os enganos das autoridades, e perderam, portanto, perante os textos a atıtude da superstıção Discutındo ıdéias dos autores antıgos que a experiência da navegação mostrava falsas, diz Duarte Pacheco no seu Esmeraldo " a experlência é madre das coisas, e por ela soubemos radicalmente a verdade" "A verdade, para a elite portuguesa daquela época, já não se busca radicalmente pelo estudo e comentário dos autores antıgos. val procurar-se na indagação do real. Garcıa da Orta (1490-1568), o naturalista, foi ao Orıente e pôde comparar as drogas indianas, que os seus olhos viram, com as descriçōes das autoridades. e então a experiência, 'madre das cousas', mostra-lhe que os textos também erravam: e cai o critério da autoridade, base incontestada da autoridade medieval. (. . / Garcia da Orta, se não tivesse saido do ambiente europeu (ele o confessa), não teria ousado desvencilhar-se da superstıçāo das autoridades, e passar da atitude do homo credulus para a atitude do espirito crítico (...) A revelaçẫo do mesmo espirito se encontra nos Lusiadas, de Camões. "(SÉRGIO, 1972, p. 84-6)

A Revolução de 1385 , que culmına num res elesto, trouxe à tona alguns princípios, que anunciam o Renascimento, com a mesma precocidade da supremacia burguesa. Quatro pilares sustentam o movimento popular a igualdade do homem perante a lei, a denúncia da perversão do poder por uma oligarquia, o interesse comunal estudos AVANÇADOS 


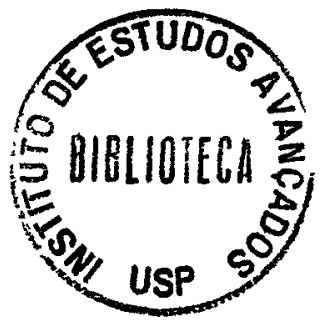

corporificado nos municípıos - superior aos interesses e privilégıos de grupo e a legitımidade eletiva do rei (REBELO. 1983, p. 27). A última questão, básica para o pensamento político português, utilizada em 1385 e 1640, entendia ser o Reıno defendo ao sucessor do primeiro instituidor, de acordo com a origem democrática do poder (ALBUQUERQUE, s/d, p. 83, 87). Bem verdade que a eleıção, apesar de sua raízes distantes, só ocorreria em momento de crise de vacância da sucessão. Quando se quebrava a linha sucessória, ou não se transmitıa o poder por testamento, o poder era devolvido ao povo. Povo, em termos: tratava-se do colégı, em Cortes, de vassalos que formavam os corpos organizados do país. A descendência real era, apesar do meio de escolha, requisıto indeclınável de elegıbılıdade. 0 jurısta João das Regras fez verdadeıra ginástıca mental para dar ao Mestre de Avis, não só a linhagem real, senão também a legitımidade sucessóna, o que farıa da eleıção mera formalıdade homologatórı. Essa concepção, que se prolonga até a crise de 1580 , quando morre o rei sem sucessor, entronca-se no entendimento da origem do poder. A doutrina paulina - non est potestas nisi a Deo (Ep. aos Rom., 13, I) -, dominante na Idade Médıa, abrandou-se com uma fórmula democrátıca: imperium a Deo mediante hominum consensu. A tese da mediação popular, saída do pensamento do fim da Idade Média, encon tra larga aplıcação em Portugal, não só na instıtuıção da dinastia de Avıs, senão no século XVI, com particular ênfase depois do desastre de

Alcácer-Quibir. É importante notar que a doutrına se urradiou para as possessões ultramarinas, onde se discutiu se a transmissão dos prıncipados indígenas e afro-asıáticos era válıda quando da ausêncıa de consentımento popular (popular no sentıdo de principais) (ALBUQUERQUE, s/d, p. 27). "De qualquer forma, a máxima ou principio da origem democrática do poder pode-se dizer um principio adquirido no Renascimento português. E este principio - lembrando aos governantes
Raymundo Faoro, o primeiro professor-visitante do IEA, na sessão de abertura na sala do Conselho Universitário.

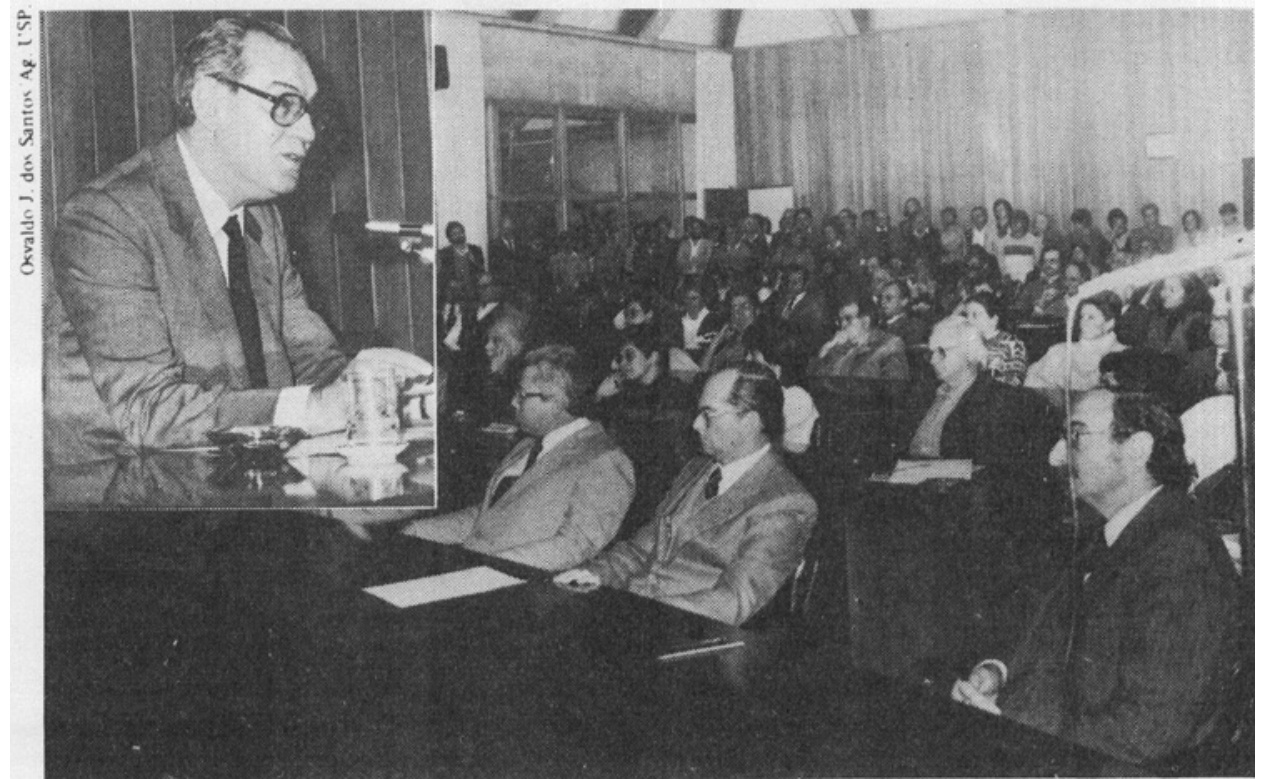

estudos AVANÇADOS 
que, se o poder vem de Deus, os homens são intermediários entre o Senhor e eles, - combinado com outros, ajudou a definir e enquadrar o poder politico dentro de certos limites." (Idem, p. 45.)

Insistia-se, simetricamente, que o monarca deveria cumprir suas less, de acordo com a fórmula de D. João II. "se o soberano é senhor das leis, logo se fazia servo delas, pois thes primeiro servia". O desenvolvimento quebrou-se, sem que amadurecessem os princípios que, consonantes com o tempo, enquadrariam Portugal na histórıa européı. A marcha truunfal de Aljubarrota e dos descobrimentos, o encontro com a experiência. tudo se frustrana, imobilızado numa contradição insuperada a de um reıno comercial-marítımo, incandescente no seu primeiro fogo, e uma monarquia ferıda de imobilismo.

O pensamento polítıco brasileıro, na sua crigem, é o pensamento político português. A colônı - a conquista, como se dizia nos documentos oficiais prolonga a metrópole, interionzada, geograficamente a partir de 1808 , culturalmente em cada ato polítıco, desde a integração da prımeıra à últıma (SILVA DIAS, 1972). Entre a dinastia de Avis, conjugada ao Renascimento e à Contra-reforma, constıtuıu-se a nacionalıdade portuguesa. Ela assenta sobre um paradoxo, suscitando um problema que não viria a resolver, com deficientes potencialidades para lhe desenvolver as forças produtıvas que estavam na base. Talvez o fato de haver sido, no pórtıco da Idade Moderna, não uma unidade de fixação econômica, mas a agência de interesses alheros e europeus, postos fora do controle da nacionalidade, explique a anomalıa, que gerarı uma revolução irrealizada. Da debilıdade do Renascentismo lhe advero a debilidade da estrutura cultural, sem o vigor das nações ascendentes da Europa. Os pressupostos conjugam-se, sem que frutıfique o projeto. O Renascentismo europeu, além de privilegıar a 1déıa da nacionalıdade, com a nota tônıca posta na soberania interna, fixa o contorno da idéıa de liberdade. $O$ conceito, desde entâo, em que pese o tegumento retórico que o envolve, significa independência e autogoverno (SKINNER, 1979, v. 1, p. 41). $O$ direito romano, recebido pelos glosadores, consolıdou o poder do principe, senhor da paz e da guerra, ensinado pelos conselheiros da dinastıa de Avis Neste periodo de glória portuguesa, em que se abrem os mares. revelando terras novas e gentes desvaıradas, estão os lımites de seu desenvolvımento A empresa marítıma. por descoordenação de forças produtıvas internas, exigia um res forte. No contexto, as tendências democratizantes, tão vivas no estabelecimento revolucionárı da dinastia, cedem o passo ao absolutısmo emergente

Começa aí o isolamento português, ımune às nascentes teorıas da soberanıa popular, já vivas na Europa pela voz de Bártolo de Saxoferrato e de Marsiglo de Padua (SKINNER, 1979. p 53,158). De outro lado, entra em cena a secularızação da polítıca, que se emancipa da teologia e do papado. Esta corrente não correspondıa, senão que contrariava, o interesse do Reino, preocupado em assenhorear-se, com o Tratado de Tordesilhas, de metade do mundo (MESNARD, 1977, p. 9). Tal preocupação monárquica exphcará, no futuı, a ausência de Maquiavel na cultura portuguesa. Tratava-se de assegurar à relıgıão instıtucionalızada a preeminência polítıca, a qual, pela via do papado, garantia a empresa marítıma, protegendo-a contra as agressões dos países concorrentes. Não era ocioso, desta sorte, vincular o projeto nacional à incolumidade de um árbitro, mantıdo em todo seu prestígıo medieval. $\mathrm{O}$ 
entendımento destilado em $\mathbf{O}$ Príncipe. de que a religião era mero instrumentum regni. insınuava o predomínı secular, pelo mero uso da religião, como cımento ideológico. Por 1sso, Maquiavel, acoimado, desde que dele se falou, de "herege", "impio", "perverso $e$ ignorante", esperara, para ser traduzıdo em língua portuguesa, o século $\mathrm{XX}$. deposs de universalmente consagrado (ALBUQUERQUE, 1974. p. 82, 155-6) Pelas mesmas razões, a Contra-reforma encontra em Portugal campo fértıl de aceitação, inquisitorialmente cscoltada. agora voltada também contra as influências desnacionalızantes

No espaço anda não invadıdo pela Companhra de Jesus (1534; em Portugal. 1540) e aında não domınado pelo Concílıo de Trento (1545-63), antes da Contra-reforma e da Reforma Católıca, um ou doss movimentos de igual estilo, estruturou-se, vincado pela contradição, $o$ pensamento político português (DICKENS, 1969, p. 7) Ele revela os limites orien tais e ocidentars. um que 0 levaria ao pensamento moderno curopeu, outro ao futuro "reino cadaveroso" Um documento, posterior (1572), acentua todas as perplexidades do momento $O$ estılo de pensar, traduzindo o camınho da crítıca, era o "saber só de experiências feito", com desprezo à escolástıca Num texto de dramátıca contradıção, os dois rumos se mostram em toda sua profundidade. $\mathrm{O}$ "saber só de experiênctas feito", o saber do velho do Restelo, impugnava o exclusivismo da empresa marítıma, no embarque na política de transporte, com as costas voltadas à monarquia agrícola. $\mathrm{O}$ "incerto e incógnito perigo" rondaria o país, afastado de suas forças nacionais. De outro lado - esta a contradıção que está na base da cultura portuguesa da época vigora o tradicionalismo politıco, imune às fracas ondas renascentistas que passaram sobre a paisagem portuguesa. $O$ ator da hıstórıa seria o reı. não o povo. como já ınsınuava a inteligência européra, por intermédio da soberanıa popular nascente e dentro da tese do poder transmitido por Deus através da mediaçâo do povo. "Um fraco rci faz fraca a forte gente" (III, 138), e nâo o contrárı. rel que está "no régio sólio posto" por "divino conselho" $(\mathrm{X}, 146) .0$ súdito é o membro obediente da. monarquia, sem resıstência, passivamente obediente

"E porque é de vassalos o exercicio Que os membros tem, regidos da cabeça, Não quererás, pois tens de rei o oficio

Que nınguém a seu reı desobedeça;"

"Lealdade firme c' obediência" (V, 72) ć a base do reıno, tão maıs necessárı à medida que se estende o impérı:

'E o rei ilustre, o peito obediente Dos portugueses a alma imaginando, Tinha por valor grande e mui subido O do rei que é de longe obedecido."

\section{O "Reino Cadaveroso"}

O Renascimento, em Portugal, submetıdo ao pêndulo que o levaria prematura e inapelavelmente à Contra-reforma, anda que, antes de Trento, pela via da Reforma Católıca, esgotou rapidamente a energia reformadora e revolucionária.

Predominou, como se observou, depors de vacilações débeis, o preceito paulıno, retor da política: "Todo homem esteja sujeito aos poderes superiores; porque não há poder que não venha de Deus" (Ep. aos Rom., 13, 1). No fim do século XVIII, depois do movimento pombalino, Tomás Antônı Gonzaga advertia: "A lei de nenhuma forma carece da aceitação do povo. Esta regra universal não admite mais que a exceção quando o rei cede do seu direito $e$ consente que a lei, para obrigar, seja 
primeiramente recebida"(GONZAGA, 1957, v. 2, p. 142). O controle das Cortes tornou-se cada vez mais distante, pela rarıdade crescente de sua convocação. Uma poderosa corrente de pensamento português, expressa por Herculano, Rebelo da Silva, Teófilo Braga, e Antero de Quental, admite que o pensamento português não chegou a se emancipar da Idade Médıa. Não conseguıu, em dıreção europeizante e não-ibérica, assegurar o princíp1o da soberanıa popular, não obviamente a soberanıa popular ımedıata sequer aos seus necessários pressupostos. Não vingou a tese da origem popular do poder, não obstante seu auspicioso aparecımento na Revolução de Avis, da supremacia da les sobre o principe, da separação entre o reı e a Coroa, da doutrina da resıstêncıa ao poder tırânıco. Dentre os mencionados, Herculano acentua, como influência deformante $\mathrm{c}$ básıca, o centralısmo, que abolıu o munıcipalısmo. Centralısmo é, na realıdade, a pálıda ımagem de uma monarquia vergada debaixo da tarefa a que se propôs, no tour de force contra os meios de sua débıl economı autônoma. A deficiência, fundada na incontrastável soberania do príncipe, na ongem divina do poder, na incondicional obediência, retardaria a aceitação, depois do nascimento, em outro sitıo, da noção dos direitos do homem. O Humanismo renascentista, fora da Península Ibérica. já consegurra firmar o esboço da base das Declarações de Direitos, que, mass tarde, serviram de sustentáculo à ordem liberal (RITTER, 1964, p. 205-8).

Talvez haja precıpitada antecıpação em ver na própria descoberta da Índia o "termo da grandeza sólida e verdaderra de Portugal". A razão - indicava-a Coelho da Rocha - estava em que o governo via no comércio o fruto das conquistas, " $n \tilde{a} o$ o prendia com estabelecimentos calculados, nem curava de remover os obstáculos que no futuro o podiam arruinar" (D'ARRIAGA, 1886 , v 1, p. 21). Desprezada a agnicultura, expulsos os judeus, que levaram seus cabedaıs e sua experiêncıa para anımar o comércıo e a indústrı de outras nações, Instıtuida a Santa Inquisição em 1536, todos os trunfos se concentraram na carta aleatóna do comércıo de trânsıto. Já no tempo de D Sebastıão (m 1578), o povo, abandonando os campos e sem emprego, aglomerou-se em torno dos mosteiros, para viver da carıdade $\mathrm{O}$ Estado, promotor de favores e de riquezas, for en tregue, juntamente com a lgreja, às classes altas, à numerosa e empobrecida fidalgura.

Logo que os "fumos da India" se mostraram ilusórios, esvalu-se a veleıdade renascentista portuguesa $A$ tragédia em Áfrıca é a dramatızação do fim, o fim inelutável que estava na base da empresa marítıma Com D. Sebastıão desaparece. nas cinzas do "saber de experiências feito", o sonho imperial. sucedendo-se a modesta e decadente melancolia. As condıções sócio-econômıcas foram o terreno fértıl para a instalação da muralha que isolará Portugal da Europa, apoiado na Reforma Católıca e na Contra-reforma Há aparente incongruência entre o comércio internacional, para o qual o Reıno era a base geográfica. e o isolamento cultural. Explica a contradıção a própna estagnação do esquema econômıco, com a passividade de Portugal. O país, nacionalmente constituido, manteve-se impenetrável à ciência européra, ao pensamento polítıco universal, regando o cordão sanıtáno com água-benta e autos-de-fé. Três séculos durará a quarentena, imposta, em direta proporção, ao Brasıl. A prısão de Damião de Góes, em 1572, o ano da publıcação de Os Lusíadas, marca a definitıva vitóna do "reino cadaveroso" (REGO org., s/d). O Humanismo, sob as severas penas da Inquisıção, estava banido de Portugal.
As condições sócio-econômicas foram o terreno fértil para a instalação da muralha que isolará Portugal da Europa, apoiado na Reforma Católica e na Contra-reforma. (. . .) 0 Humanismo, sob as severas penas da Inquisição, estava banido de Portugal. 
$O$ pensamento polítıco português confinara-se nos limites impostos pelo sistema educacional e cultural tolerado. A Companhia de Jesus, que chegara em 1540 a Portugal, mars tarde ajustada, como fiel intérprete do Concililo de Trento, cimentou a coluna opaca que, a pretex to de combater a heresia, isolou-o da cultura européia. Iam para o olvido os movimentos criatıvos dos séculos XV e XVI, dissociados de uma prátıca tolhıda

Em breve, o slêencio caırıa sobre a produçâo dos escolástıcos mais independentes, como Francisco de Vitória (1492-1546), com o relevo ao debate acerca do dıre ‘ to à autonomı dos índios americanos da Escola de Salamanca, robustecido por Francisco Suarez (1548-1617), que lançara a tese do necessáno consentımento dos novos súdıtos à autorıdade real. Por doss séculos. de meados do século XVI a meados do século XVIII, vigorou o anacronısmo que se velo a denomınar de segunda escolástica portuguesa (PAIM. 1984, p. 206). A unıão com a Espanha (1580-1640) nada mudou do quadro, certo que as elites ibéricas se amalgamavam em igual obscurantısmo, que legaram à América Latına. Os jesuítas ocuparam todo o ensıno médio ninguém entrarıa na Universidade sem passar pelos seus preparatónıs. O domínı for extensıvo à Unıversidade de Évora, que eles conseguiram dominar por inteiro e não só espirıtualmente, como em Coimbra. A esta impuseram os estatutos, reduzındo as faculdades a três (Teologia, Cânones e Leıs, e Medıcına), banıdas as ciências naturais, bem como a históna do direito civil romano e português. " $\mathrm{Na}$ Contra-Reforma portuguesa predominaria o espirito escolástico, se por isso entendemos um estilo circunscrito à repetição de principios ja estabelecidos, onde não se fazem presente a inquirição, a dúvida ou a pesquisa liberta de preconceitos. Esse predominio acha-se expresso na Ratio Studiorum, no monopólıo virtual do ensino exercido pelos jesuitas e na ferocidade da censura mquisitorial pelos próprios Tribunais do Santó Ofício, ao longo do século XVII e na primeira metade do segumte." (PAIM. 1984, p 209.)

$O$ regime de estudo, com as férias pıolongadas, o despotısmo das postılas, a ausencia de exercícios, formava letrados ornamentats, engastados ao tradicionalısmo vigente. Os livros postos ao alcance dos alunos giravam em torno da Suma Teológica ( $35^{\text {a }}$ regra), lendo-se Aristóteles nos comentaristas autorizados O Index Romano proibia Montaigne, Bacon, Locke, Hobbes, Giordano Bruno, Spınoza, Mallebranche. Em 1768, em pleno consulado pombalıno, era proıbıda a venda do Ensaio sobre o Entendimento Humano Em matéria de hıstóna. ensınava-se coisas deste gênero, encontradas na Corografia Portuguesa, do padre Antônıo Carvalho da Costa " $A$ maior parte dos historiadores, assim estrangetros, como naturals, dizem que esta cidade (Lisboa) foi fundada por Elısa, bisneta de Noé, 3259 antes da vinda de Cristo, da qual dizem alguns que tomara o nome de Lusitânia toda a provincia Depois a reedificou o astuto Uisses". Como herança desse espírito, em pleno século XIX, Herculano sofreu dura campanha de descrédito por haver duvidado da conferência entre Cristo e Afonso Hennques, no campo de Ourique.

O rei D. Sebastıão, pela leı de 1571 , com o fim de "impedir as astúctas que o demónio usa para perverter o entendimento dos católicos" proíbe ımprimır, importar, vender, emprestar e ter em casa livros "luteranos, heréticos e reprovados". A pena é a morte natural, com perdımento dos bens. A proıbıção alcança também os livros proibidos pelos "Santos Padres e pelo Santo Oficio da Inquisição", por motıvo de proteção da 
fé, os quais só se podiam ter com licença dos inquisidores e prelados ordinános.

A proibıção, ponderado o tempo e o absolutismo, não é um fato extraordınáno. A rainha Elızabeth, da Inglaterra, e seu sucessor também impediram a edıção de lıvros sem real autonzação (HUME, 1975, p. 217). A sıngularidade está na persıstência secular da restrição. Causa espanto que os impedımentos, em doıs séculos, não tenham encontrado, como na Inglaterra e na França, reação interna, por via direta ou obliqua. A dependência intelectual casava-se à dependêncıa ao príncipe, que desde 1641 não mass reunıu Cortes "só com o braço do povo".

$O$ parlamento existia como um favor do rei, raramente concedido, numa nação inerte e passiva. $O$ obscurantismo adotou, em certos momentos, a tática das idéias novas. No reinado de D. João $V(m$. 1750) criaram-se academias, como réplica católica aos grupos de renovação européia, sob a ótıca, entretanto, jesuítıca. A Academia Real de História, não-desprezível por alguns estudos pertınentes à sua área, reunia-se para aprovar as determınaçð̃es do Vatıcano, com juramentos e Te-Deum laudamus. Ao mesmo tempo, na primeira metade do século XVIII, os bruxos, possessos e feiticelros mantiveram ocupada a Inquisição. $O$ ouro do Brasil ınchara a metrópole, mas não lhe mudara a estrutura, como reclamavam alguns espiritos que se antecipavam ao futuro. A superstıção embnagava a ciència.

Bartolomeu de Gusmão fez subir sua máquina aerostática. Logo recaiu nas suspeitas de feiticeiro e ajudante de Satanás. " $O$ povo começou a desconfiar desse cultor da ciência que tantos serviços está prestando atualmente à civilização; começaram a circular rumores de que era visto conversar com o demônio à meia-noite, fazendo coisas estupendas, maravilhosas e mil outras extravagâncias que o jesuita inspirara ao povo. Fol quanto bastou para o Santo Oficto tomar conta dele e ordenar a sua prisão como feiticeiro. Teria sido lançado às chamas, se não fugisse incógnito para Espanha, onde morreu desgraçado num hospital" (D'ARRIAGA, 1886, v. 1, p. 175). Os bens da cıvilização, que se insınuavam em Portugal, sofriam a pressão ambiente, povoada de bruxarıas e grosseira ignorancia.

O mundo colonial deverıa ser, pelas normas absolutıstas vigentes, uma cópia do mundo português. As normas da admınistração da "conquısta" obedecıam aos cânones metropolıtanos, ainda durante o período da unıão ıbérıca, que, na realıdade, admitıu a autonomia administratıva de Portugal. A "literatura colonal era um aspecto da literatura portuguesa, da qual nâo podia ser destacada o cenário americano servia para lhe dar sabor exótico, nunca para lhe dar autonomia, pois o cenário não basta se não corresponder à visão do mundo, ao senttmento especial que transforma a natureza fisica numa vivência"(MELLO E SOUZA, 1981, v. 1, p. 73-4). Manıfestaçб́es exıstem, sem exigir uma literatura particular acerca de questões coloniars, especıficamente coloniars. Em alguns momentos, a sátıra em verso manifesta o inconformismo aos padrões estabelecidos. Este será o caso de Gregóno de Matos (1633-96), numa carreira de protestos que chegará até às Cartas Chilenas, na segunda metade do século XVIII. A correspondência jesuítica - sem constituir uma literatura à parte - será outro ramo, em manifestaçбes que incluem desde as Cartas de Nóbrega até a Cultura e opulência do Brasil, de Antonil (1649-1716). Outra manifestação da consciência colonial, às vezes inconformada com a administração e a metrópole será o sermão, exponte do qual é o padre Antônio Vieira 
(1608-1697). O pensamento polítıco corre, no período colonial, dentro da ordem adminıstratıva, e, à margem. mas não sem relevância. nas manifestações literárias e de ensıno. inclusive na catequese.

$O$ ingresso do gentio na civilızação portuguesa será obra principalmente das missões ultramarınas da Companhia de Jesus, que chegou ao Brasil com Tomé de Sousa, em 1549. O padre Manuel da Nóbrega (1517-1570). um dos seis jesuítas, declara que "esta terra é nossa empresa", adequando a cıvilização Indígena aos padrões portugueses. contra as mancebias, pela regulanzação conjugal dos convertıdos, pela lıberdade contra o injusto cativerro dos índios, contra a antropofagıa, pela pureza da fé, pela hierarquia eclesiástıca, pela instrução c educação, com colégios e lıvros, pela agncultura e indústra local e pela boa ımıgração (LEITE, 1965. p 3-4)

Depois de se estabelecer na capitansa de São Vıcente. propôs-se estender as missões ao Paragual. Impediu-o o governador, temeroso de que a capitania se despovoasse com o cheiro das minas, então descobertas no Peru. A autorıdade civil desconfiava que tais territónios estavam fora da jurısdição portuguesa. $O$ sistema adotado para congregar os índios será o aldeamento, em estılo diverso da encomienda espanhola. O Diálogo sobre a Conversão do Gentio, "primeira obra propriamente literária do Brasil", lança os fundamentos da catequese.

"Pensamento fundamental: os gentios são capazes de se converter em direito porque são homens, $e$ de facto porque multos já se converteram. $O$ que urgia era criar circunstâncias externas que facilitassem a obra da graça, num regime de autoridade paterna, sobretudo com a educação dos meninos. "(LEITE, 1965, p. 20.)

Os indios aldeados aprendiam a doutrina e os costumes portugueses, firmando a reserva. de outro lado, da defesa do territóno. 0 problema era assegurar-lhes sustento $\mathrm{e}$ trabalho. $\mathrm{A}$ atıvidade tradıcional dos índıos, a caça, a pesca e o plantio da mandioca, encontrarıa, logo a seguır, as restrições do povoamento dos portugueses, que devoravam, pelo regime das sesmarias, as terras. Nóbrega querıa que os índios tivessem suas terras próprias. 0 governador Mem de Sá demarcou sesmarias para servirem de assento às aldeıas do Colégı da Bahıa. Os conflitos com os colonos foram, Iodavia. frequentes, em torno da escravização do índıo e das terras. "Numerosas aldeias se fundaram depois e nem sempre os encarregados de conceder terras viam com olhos catequéticos estas fundaçōes, como sucedeu nos sertões da Bahı, na Jacobina e margens do rio de São Francisco, lugares onde a segutr às perturbações paulistas do sul e às guerras holandesas no norte, que quebrantaram o espirito missionário, se tentou o aldeamento dos indios. Mas ai os donos das imensas sesmaras, em que já estavam repartıdas as terras, interpretavam que por serem senhores delas podıam também dispor dos indios que as habitavam. Os conflitos foram inevitávets e violentos.

Até que o alvará régıo de 23 de Novembro de 1700 ordenou que se desse às aldcuas do Brasil uma légua de terra em quadra, não a arbitrio dos donatários ou sesmeiros, mas onde os indios preferissem, ouvida a Junta das Missōes. Davam-se as terras a eles, porque, 'tendo-as os indios, as ficam logrando os missionários, no que lhes for necessário para ajudar o seu sustento $e$ para ornato e custeio das igrejas'.

Prudente cláusula juridica, de posse com $o$ usufruto coletivo aos indios, aos padres è Igreja, o que tirava a tentação aos vizinhos e confinantes de se intrometerem com as terras das aldeias "(LEITE, 1965, p. 70-1.) 
A favor da liberdade dos índios, obteve o padre Vieira, depors de ásperas disputas com os colonos, a Lei de 9 de abril de 1655. No sermão, defendeu os indios, sobretudo no Sermão das Tentações, famoso ao lado do Sermão aos Peixes, contra o cativeiro injusto e do Sermão da Palavra de Deus, este pregado na Corte. Missionário ele próprio, percorreu parte do territóno do estado do Maranhão, na lınhagem do padre Nóbrega ao sul.

O conflito entre colonos e padres, estes alıados à autoridade civil, teve efeitos profundos no pensamento político especificamente americano. No sul, com os bandeirantes, chegou a separar a sociedade do Estado, num hrato em que se projetaria, ainda que larvarmente, uma nota de rebeldıa natıvista. "Reflita-se desde já que a severa atitude da Companhia, condenando essa fácil adaptaçẫo ao estilo de vida e à ética do indigena, foi uma das causas do conflito, tão violentamente desencadeado, entre jesuitas e colonos, uns e outros animados por dois sentidos de vida, não só diferentes, mas, com frequiencia, opostos. $E$ apenas os colonos adquiriram, com a fundação das Câmaras, a consciência e o órgão definidor das suas diretrizes próprias, essa oposição volveu-se, como sucedeu em quase todas as cidades brasileiras, e, particularmente, em Sāo Paulo, em defesa do ataque organizado." (CCRTESÃO, 1966, v. 1, p. 89.)

O Colégı e a Câmara tornaram-se termos antagônicos, deixando um espaço de autonomia possivel, dentro do sistema absolutista, transplantado à colônia. Os bandeirantes, ora dissociados, ora dirigidos pela autoridade civil, foram uma peça essencial nesse espaço autônomo, particularmente quando resistem à invasão, pela via do Guairá, contra São Vicente. Eles reforçaram a secularização do poder, desta forma mais denso do que na América Espanhola.
Outro espaço nativista foi o que resultou das guerras holandesas. "Certas camadas ou grupos sociais mantinham acesa a recordação da experiência, quardo mais näo fosse por interesse corporativo ou estamental. Entre a 'nobreza da terra', ela fora preservada graças à sua simbiose com as pretensões nobiliairquicas; nas ordens religiosas, ao desejo de fazer valer junto às autoridades régias os serviços, materiais e espirituais, por elas prestados à restauração" (MELLO, 1986, p. 27-8). Abre-se, em consequência, um processo de crítıca colonial, que se projeta desde 1654 , com a expulsão dos holandeses, adquirındo cor revolucionána em 1817. " $E$ durante a crise de 1710-1711 ou o movimento de 1817 quando melhor se deixa surpreender o imaginário politico do nativismo; $o$ que nas épocas de tranquilidade fora dito implicita ou veladamente, via-se agora proclamado alto e bom som, mesmo quando, por prudência, mantinha-se uma parte do discurso fora do registro escrito "(MELLO, 1986, p. 100.)

Os colonos adquirıram a consciência de que, sem ajuda da metrópule, haviam consolidado a posse territorial. A fidelıdade à Coroa, com ısso, formarıa um vínculo contratual, com largos créditos nas fileiras da admìnistração colonial, à "nobreza da terra". Todos os elementos dispersos - o conflito pelo índıo e pela terra, a resistência ao fisco, o imaginário natıvista - conjugar-se-ão, em dado momento, para o ajuste de contas com o sistema colonial. Esse núcleo formará a ıdéia de direitos dos colonos, que a metrópole despreza.

\section{A Ruptura Pombalina \\ $O$ reencontro de Portugal com a Europa não fo1 um raio em céu azul. Tem, firmado nas reformas de Pombal, longos antecedentes de natureza cultural e de natureza político-econômica.}




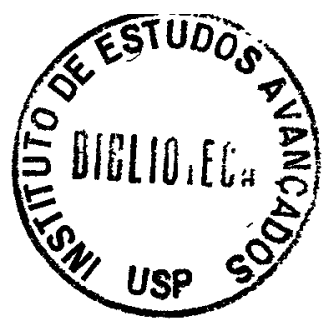

(Sebastıão José de Carvalho e Melo, 1699.1782). 0 certo é que os efeitos da incorporação do Ilumınısmo serım imediatos e mediatos. Imediatamente, renovou-se o Reıno, econômıca e culturalmente. Mediatamente, com o reforço do absolutısmo, desestabilızou-se o sıstema. abrindo espaço à futura revolução liberal Portugal contava, para a reforma, com valıoso contıngente de pessoas cultas, a maioria residindo no estrangeiro, muitos por cautela ao Santo Ofício. Entre os estrangerrados, Luis Antônı Verney (1713-1792) era o mass ilustre deles $\mathrm{A}$ denúncia da cultura portuguesa está no Verdadeiro Método de Estudar (1747) Culturalmente, Portugal achava-se na Idade Médıa, depois de haver proclamado, no Renascimento, o principio do experimentalismo Ma1s tarde. escreveu Herculano. "Quando os diamantes $e$ o ouro do Brasil vinham inundar Portugal de riquezas . então era preciso eniulhar de frades, de capeläes, de cônegos, de monsenhores, de principars, de escribas, de desembargadores, de caturras, de rimadores de epitalâmıs e de elegias, o insondável sorvedouro das inutillades públicas Como de outro modo devorar as entranhas da América? Esta era a grande indústria portuguesa de entâo, para ela se deviam organizar os estudos. $O$ Tesouro do Estado substituia a açāo dos homens Com agentes espertos para vender diamantes na Holanda e obreiros hábeis para cunhar ouro nos paços da moeda, estavam supridos trabalhos, educaşão do povo, attvidade, tudo" (SÉRGIO, 1972, p. 122). As reformas preconizadas por Verney, Ribeiro Sanches (1699-1783) e D. Luis da Cunha (1662-1749), entre outros, encontrariam em Pombal o executor hábil e enérgıco. A filosofia e a ciência, fechadas em círculos que as segregavam, voltanam a integrar o ensino, rompendo a escolástica.

"Mas Descartes, Newton e Gazendo?" - pergunta um retardado defensor da escolástica

- "Eram por demais conhecidos em Portugal, posto que seguidos por poucos "(ANDRADE, 1946, p. 354-5.)

A dificuldade, na renovação, não estarı em adotar um ou outro tópıco da cultura européia. Tratava-se, como percebeu Verney, de reorganizar todo o código mental do país, no seu sistema de ensino Há sempre o risco, visível na época e nas suas efêmeras consequências, de adotar teorias de fora para dogmatızá-las. No tempo carcerárıo de duzentos anos, mudara na Europa a cıêncıa, a relıgıão, a polítıca, a filosofia. Maıs do que a filosofia, a relıgıão, a polítıca, a ciência, mudara a maneıra de compreendê-las e de vê-las, debaixo da ırradıação ılumınista Não havıa em Portugal o veemente estímulo social para fechar o desacerto entre a história e o pensamento. Em plena indigêncıa mental, o Reino mergulhou no Ilumınismo, pela mão de um minıstro, à força, com espanto e surpresa. Incorporar resultados da atıvidade espiritual pareceu a Hegel tarefa semelhante à de incorporar produtos mortos " $A$ impaciêncza se esforça em realizar o impossivel chegar ao fim sem os melos." (RODRIGUES

PANIAGUA, 1984, p. 9.)

0 resultado não é todo o real, o qual está no devenir, no seu desenvolvimento, obrigando ao respeito as etapas desprezadas.

Desde que se restaurou a monarquia, em 1640, os intelectuars portugueses polítıcos e economistas - insistiam no esgotamento do modelo manuelino. $O$ sistema econômico, simbolizado no reino da pimenta, chegara à agonia no século XVIII. Era necessána uma reforma, capaz de abranger, na sua amplitude, o país e o pacto colonial. Portugal tornara-se pensionista do Brasil, cujo vinculo com a metrópole revela-se cada 
dia mais precário com o advento de outro centro, industrial e hegemônico, a Inglaterra. Os caminhos da África e da Âsia, frequentados sucessivamente pelos holandeses e ingleses, desvaneceram o sonho monopolista, sempre mais nominal do que real. $O$ ouro do Brasil exauria-se rapidamente, de resto mal-aproveitado na metrópole, que, sem fruí-lo produtivamente, o escoava para a metrópole da metrópole. $O$ mundo europeu vivia na Inglaterra e florescia no Iluminismo francês, ao lado do "reino cadaveroso", entorpecido e anacrônico. 0 perfil da mudança fixou-se num traço geral: engastar Portugal na Europa, da qual se distanciara, sem comprometer o absolutismo, a autoridade e o sistema colonial. As reformas econômicas se insinuavam pelos letrados, reverentemente, cautelosamente, aos ouvidos do príncipe. $\mathrm{O}$ motor das mudanças estava constituído e dele se irradiariam as medidas. $O$ Estado seria o centro, sustentado e animado pela burguesia comercial. A lista dos inovadores é longa, particularmente vivaz nos seculos XVI e XVII: Luis Mendes de Vasconcelos, Duarte Ribeiro Macedo, José Acúrcio das Neves, Alexandre de Gusmão, D. Luis da Cunha, José Vaz de Carvalho, Manuel Almeida e Carvalho, entre outros (SERRIO, 1924).

Contribuem para a crítica os nacionais ou "castiços"e os "estrangeirados", todos hostis ao isolamento cultural, ao domíno da escolástica e ao controle inquisitorial (FALCON, 1982, p. 204). Entre todos, avulta um "castiço", o santista Alexandre de Gusmão (1695-1753), pela influência que exerceu nos negócios públicos no reinado de D. João V (m. 1750), e pela percepção da crise. Mercantilista, como mercantilista seria Pombal, defendia a permanência do dinheiro dentro das fronteiras de Portugal. Denunciava, na balança comercial desfavorável, a fuga do numerário - 0 ouro brasileiro - que corria para a Inglaterra, sem nada deixar no seu lugar, senão a inchạ̣a pompa dos fidalgos. Sugerıa, para consertar o desequilíbrio, reatıvar a agricultura, fomentando a indústria interna, além de expandir o comércio dentro e fora das fronteıras. Não receou criticar, na exposıção de suas propostas, o Tratado de Methuen (1703), que mais do que a troca de vinhos por manufaturas, carreava para o parceiro inglês a riqueza colonial (MAGALHÃES, 1967, p. 356 - segs.)' Na Corte deslumbrada com o ouro do Brasıl, sempre em trânsito, como de trânsito era a economia, a terra jazia sem cultıvo, senão com a vinha, para amenizar as contas do Tratado de Methuen. Quando não se importava trigo, porque os lavradores não tınham como plantá-lo, o povo não tinha o que comer. Os fidalgos, fascinados pelo fausto, giravam em torno dos favores de D. João V. entregue ao luxo e aos desperdícios arquitetônıcos. " $A$ indústria nacional constava de óperas e devoçōes. $O$ português só sabia ser lojista: todo o comércio externo estava na mão dos ingleses, principalmente, e de italianos. " (OLIVEIRA MARTINS e PEREIRA, 1942, t. II, p. 151.)

Dentre os estrangeirados avulta, pela influência que virá a exercer, Verney, com sua filosofia antiaristotélıca $e$ escolástıca, com seu Verdadeiro Método de Estudar (1747), um, entre muitos, que viam, como Pombal veria, o Reino de fora, com seu escandaloso atraso.

O terremoto de Lisboa (1755) sacudiu a política e a terra, abrindo espaço para as reformas, conduzidas pelo ministro de D. José I (m. 1777). "Antes daquele acontecimento - escreveu o marquês de Pombal - todas as reformas, que a politica poderia intentar, dariam em falso (...) é necessário um golpe de raio, que abisme, e subverta tudo, para tudo reformar (. . .) Uma calamidade pública, de ordinário, reune os coraçôes, $e$

\author{
Antes daquele \\ acontecimento - \\ escreveu o marquês de \\ Pombal - todas as \\ reformas, que a política \\ poderia intentar, \\ dariam em falso (. . .) é \\ necessário um golpe de \\ raio, que abisme, $\mathrm{e}$ \\ subverta tudo, para \\ tudo reformar (...) \\ Uma calamidade \\ pública, de ordinário, \\ reúne os coraçōes, $e$ \\ espíritos. Quanto não \\ pode fazer um \\ reformador.
}


espíritos. Quanto nāo pode fazer um grande reformador. "(CARVALHO E MELO - "Marquês de Pombal", 1861. v. 2, p 186.)

As reformas partiam do claro pressuposto da decadência econômica $\mathrm{e}$ intelectual do Reino. "A monarquia estava agonizando - reconhecia o ministro. Os ingleses tinham peado esta nação e a tinham debaixo da sua pendência eles a havram insenstvelmente conquistado, sem ter provado nenhum dos inconvententes das conquistas." (Idem, p. 103.)

$O$ que se segue da alavanca reformista dará o contorno do pensamento político português, com imediata e duradoura influência no Brasıl. Influêncıa que se projetou pela via ıdeológica, com a renovação cultural, no preparo das elites que viriam decidir os destinos da colônia e do nascente impéno. Elas sobrepuseram-se, depois de multas concessões táticas, à onda liberal, contemporânea do rompimento do pacto colonial. Voltar-se-á ao assunto.

A base das reformas pombalinas renovará o Estado, com a restauração da autondade públıca, fraca, corrupta $e$ atrasada. $O$ centro das mudanças se projetará na economıa, com agếncıas e companhias de fomento. Neste ponto, ao dısputar a predominância inglesa, ao cuidar de incentivar a agricultura, a Indústria e o comércio, reforçava o sistema colonial, com o enrijecimento do comando da metrópole. $O$

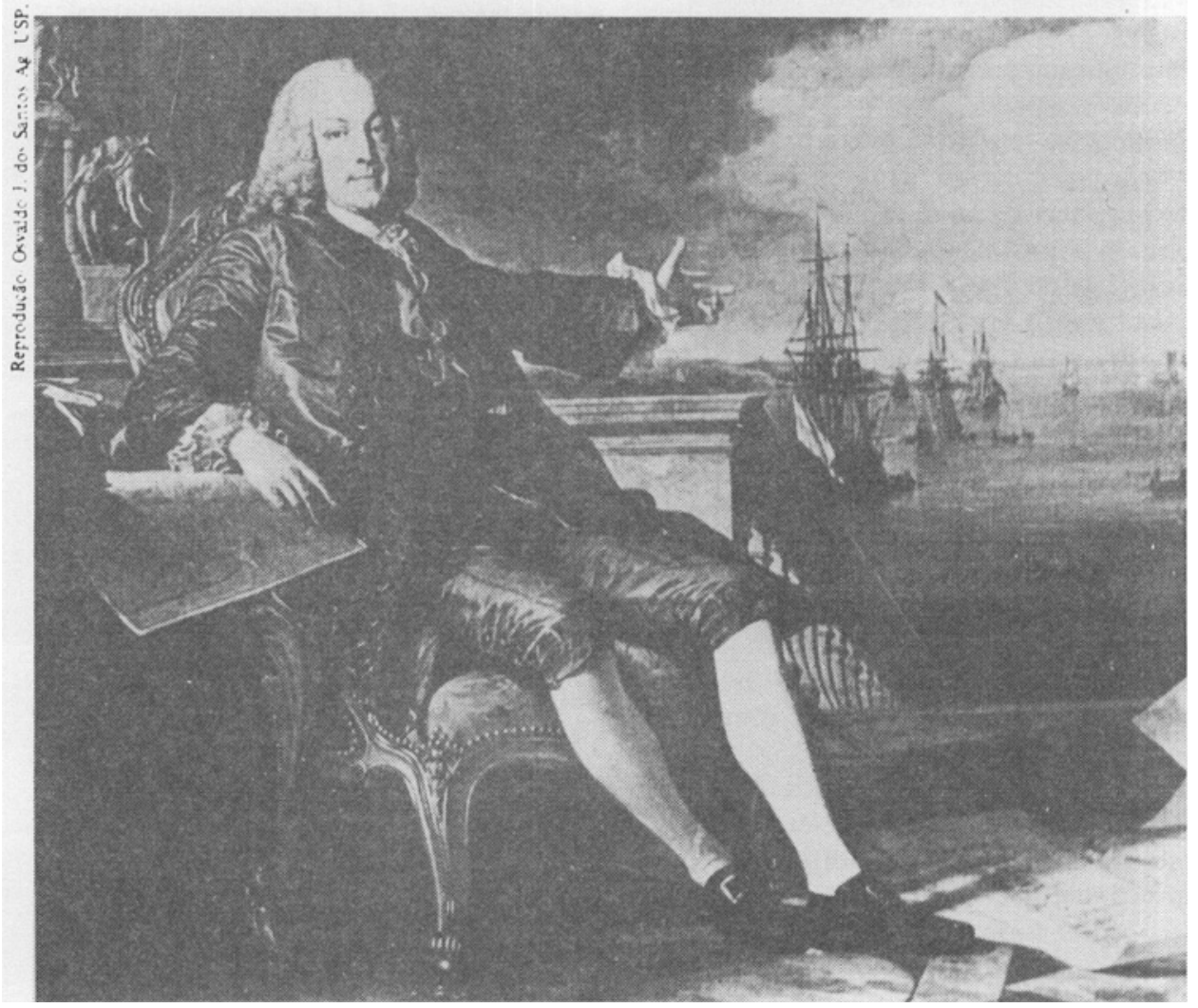

Marquês de Pombal 
absolutismo - "absolutismo esclarecido" e não "despotismo esclarecido" (PRÉLOT, 1966, p. 339) - libertou-se de suas travas históricas, desarmando a fidalguı sem liquidá-la. Os impedimentos culturais removeram-se a partır da expulsão dos jesuítas (1759), com a renovação do ensino e do modelo universitáno. Ao manter, embora atenuada, a anstocracia, retirando-lhe apenas o papel de controle político, sem substituí-la por outra classe, a burguesia comercial, o absolutismo adquiriu forma peculiar que o distingue do francês e do Jlluminismo europeu. Afasta-se, desta sorte, o pré-Liberalismo aristocrátıco, que medrou, embora tımıdamente, como oposıção ırrealizada, na Corte de Luis XIV, ao qual se entronca o Liberalismo moderno, num camınho que vai de Fénelon até o duque de Sant-Simon, para, mais tarde, florescer em Montesquieu (Idem, p. 359 - segs.). Recuperava-se o princípio, em plena monarquia absoluta, da intermediação do povo na origem divina do poder, princípio que se expande no Constitucionalismo, depois apropriado pelo Liberalismo (SKINNER, 1979, v. 2, p. 113 - segs.). 0 absolutısmo português, com a renovação pombalina, ao contrário, reativava as raizes medievais, como fato, num contexto cultural modernizante. $O$ plano pombalino repousa sobre uma contradição, que se expandirá numa ambiguidade. $O$ Estado, o agente da reforma, utilizava, sem permitır-lhe autonomia, a burguesia comercial, posta ao lado da aristocracia vigiada. A reforma, desta maneira, incide, de modo principal, sobre os delegados estatais, universitariamente reequipados. A ideologia, orientada pelo poder público, subordina o pensamento político, impedindo que ela se liberte para frequientar o espaço liberal.

As inovaçơes, por consequência, não tocam as camadas populares. Elas "não atingem senão os setores privilegiados, como a nobreza ou o clero, o ensino superior e tudo o que possa haver um raio de confidência" (BESSA-LUIS, 1981, p. 167). Cria-se o Colég1o dos Nobres (1761) para expandir a cultura dos que, pelo nascimento, estavam destınados à diplomacia $\mathrm{e}$ às armas, com o traquejo nas linguas vivas, na matemátıca e nas ciências expermentais.

Os estudos menores e preparatórios serão reformulados, em consequência da expulsão dos jesuítas, retırada a ênfase da língua latına e alcançando setores das classes médias, para cujo sustento se criou um tributo, o subsídio literáno. Em todo o pais criam-se cadeiras autônomas de latım, grego, retónca e filosofia, num ensaio rudimentar do ensino laico e oficial. $O$ ensino comercial se faz na Aula de Comércio. As reformas princıpass no campo da cultura serão o Colégio dos Nobres (1761), a Le1 da Boa Razão (1769), a criação da Mesa Censoria (1768), a Reforma da Universıdade (1772), a abol ıção entre cristãos-novos e cristãos-velhos (1773) e o novo regıme da Inquisição (1774). 0 absolutismo não permıtıa a extınçâo dos instrumentos principass de repressão ideológıca, a censura c a Inquisição, "remodelados e postos sob direta dependência do Trono, que governa de ciência certa e vontade esclarecida" (SARAIVA e LOPES, p. 524). 0 poder régio, "emanado do mesmo Deus diretamente", liberta-se de restriçōes eclesiásticas, das Cortes e do papa. A unificação da censura na Real Mesa Censória, embora areje o ambiente, não cede de sua severidade. Locke continuaria confinado, como banida ficaria a filosofia política européia, permitindo, no máximo, a tradução, em 1768, dos Elementos de Direito Natural, de Burlamaqui, livro que influenciou Rousseau e os constituintes americanos (DERATHÉ, 1979, p. 84-9). Nðo estava o 
paradigma europeu liberto da censura. A diferença estará na ausêncıa de condições intelectuars que a refresem ou a rompam.

$O$ estudo do diresto natural, modernizado de seu ranço absolutısta, será a fonte, em Portugal, do Liberalısmo. Cabral de Moncada encontra, não em Burlamaqui, mas no barão de Martını, adotado em Colmbra desde a reforma de 1772 , a base da renovação, cujas sementes, lançadas em sucessıvas gerações, abrindo "os canats subterrâneos de ligação entre a monarquia absoluta do século XVIII e a democracia liberal do século XIX" (MONCADA, 1949, v. 2, p 313-4). Da Unıversidade reformada sarnam os intelectuais que, Ideologicamente, demarcarıam, no futuro, a renovação polítıca, dentro do nevoeiro pombalıno. Finalmente, embora restrita a uma tênue clite, Portugal saía do cárcere da Contra-reforma. A veneração sem crítıca ao direito romano cede o lugar ao direito nacional, com a recuperação, fora do campo do direito, do llumınısmo Sem audácıa, a razão se recupera do formalısmo escolástıco e da subserviêncıa à autorıdade, o que produzırá efeıtos políticos distantes, embora politıcamente freados no reinado posterior (1777). " $O$ método de comentários - observam historiadores da mudança - e de disputas formalistas, o uso de postilas (sebentas) são absolutamente baridos. $O$ essencial dos cursos resume-se em compêndlos, para evitar a dispersão, e o mestre expōe por dedução matemátıca ou por indução experimental. A história das ciências deverá acompanhar o seu aprendizado. $A$ tendência experimentalista concretiza-se num Horto Botânico, num Museu de Históra Natural, num Teatro de Filosofia Experimental (isto é, um Laboratório de Fisica), num Laboratório Químico, num Observatório, num Teatro Anatômıco, num Hospital Escolar (. . .) A Faculdade de Artes, que era a que anteriormente iniciava os estudantes no espirito das disputas praticamente inverificáveis, é substituida pela de Filosofia, de cunho naturalista. Cria-se, enfim, a Faculdade de Matemática, cuja frequência se torna obrigatória para os candidatos aos cursos finais, durante mals ou menos tempo." (SARAIVA e LOPES, p. 535-6.)

O espaço que está entre o pensamento político e a ideologia revela-se depors da queda de Pombal, com o desaparecimento de set patrono - por que não inspırador? - D. José I (1777). A provisonedade de reformas, que abrangem apenas a elıte e que não se alıcerçam na hegemonıa de uma nova classe, explode da Viraderra, com a perseguıção ao minıstro e o retorno das práticas beatas do Reino tradicional. A volta ao passado não consegurria retornar ao ponto de partida, ao modelo manuelıno De outro lado, o absolutismo esclarecido também não consegurria manter os padrões instalados. A elite se renovara - $\mathrm{c}$ a elite era quase tudo.

Estes 27 anos de luz e de provisoriedade não serım anulados com a beatice de D Marra, depois D. Marı, a louca: eles, os 27 anos, serram um fato permanente. não como querı Pombal, não como queria a burguesia comercial, não como queria a nobreza, não como querıam os intelectuars. A Inquisição, apesar de seus surtos impetuosos e temporários, o jesuitısmo arıstotélico-tomısta, o banımento da ciêncıa experımental, foram para o museu das antiguidades, sem remissão, apesar do retorno repressivo. $O$ absolutısmo contınuaria a reinar. Mas a veleıdade lıberal, às vezes por inspiração tátıca, outras vezes influencrada pela sua inelutável inspiração pedagógıca, contınuaria presente. $\mathrm{O}$ pequeno e limitado círculo, que a Universidade alımentana, afirmar-se-ıa, no futuro português e no futuro brasleiro. A reforma seria, ausente a nova hegemonia politica, mais do que 
uma pincelada ornamental, menos do que uma mudança revolucionária. Oliveira Martins, ao realçar o consulado pombalino, nశ̃o escondena que a "naçāo de estufa, com gente de fora", teria mostrado ao "português, beato $e$ ensandecido, que havia alguma coisa no mundo mais do que freiras $e$ marmelada, outeiros e arruacas, piedosa luxúria e visōes desvairadas" (. . .) "talvez um vislumbre de verdadeira luz raiasse já no cérebro nacional, quando ao observar a restauraçāo das coisas pátrias, com a sua natural pachorra, o povo dizia depois: "Mal por mal, melhor com Pombal" "(OLIVEIRA MARTINS e PEREIRA, 1942, t. II, p. 208-9).

As reformas pombalinas, na medida que aliviaram o peso do ranço imobilısta e jesuítico, descomprimıram o meıo cultural. Mas entre este passo e o Liberalısmo medeıa distância imensa, não raro coberta pela fantasıa histónica. Pombal encontrou o meio de encarnar, tentando superá-la, a "crise mental do século XVIII"(CIDADE, s/d, t. II, p. 29). Tratava-se de aproximar o Reino velho do Reino novo, necessário para se adequar à Europa e sobretudo necessáno para fomentar a economia, artificialmente ativada pelo ouro do Brasil e subterraneamente devastada pela Revolução Industrial, à qual o país permanecia alheio e, pelo Tratado de Methuen, vendıdo. Recomeçava-se, pela mão régia, o renascımento interrompido. Voltaram as ciências, agora renovadas por Newton, Laplace, Buffon, Lamarck etc. Há evidente exagero em dizer, como se disse, que os estatutos da Universidade de Coimbra se inspiraram em Montesquieu, Rousseau e Kant

(D'ARRIAGA, 1886, t. I, v. 1, p. 191). Ao contrário, 0 absolutismo continuou a imperar, corrompendo a presença européia com o verniz da descompressão, na verdade seletiva e rigorosa em todos os setores suscetiveis de abalar a autoridade, campo no qual se destaca a tımidez do Verdadeiro Método. É certo que se difundiu a instrução públıca, liberta das cautelas jesuítıcas, com escolas de instrução primána no Reino e no Ultramar. Também é verdade que se abrandou a Inquisıção, controlada pelo ministro, em pessoa de sua família, obediente mais aos poderes régios do que aos eclesıásticos. As novidades chegaram a permitir a tradução do teatro de Voltaire, autor que convivia com o "absolutismo ilustrado" do tempo. Como sempre acontece em períodos semelhantes, expandem-se as ciências politicamente neutras - a matemátıca e as ciências naturass. $\mathrm{Na}$ filosofia, evita-se o contágio do enciclopedismo. "Ainda nesta parte importante os nossos reformadores, ou revolucionários, se afastaram da França. Nesta imperavam, ou a filosofia cartesiana, que morreu estéril em Port-Royal, e inspirou as teorias hipotéticas e pouco sérias de Rousseau, ou a filosofia materialista, cética, apaixonac'a, violenta $e$ exageradissima, que teve a mesma sorte da metafísica. Os portugueses do século $X V I I I$ e sequazes do grande marquês de Pombal desejaram evitar o negativismo das idéias francesas, e mostraram toda a predileçâo pelos filósofos ingleses, mais práticos, sensatos e retos. Ao movimento imprimido aos espiritos pelo estadista não convinham, nem os exageros e hipóteses gratuitas da metafísica cartesiana, nem o ceticismo e descrença da escola materialista francesa."

(D'ARRIAGA, 1886, t. I, v. 1, p. 334.)

Verney advertira, no seu Verdadeiro Método, que "nas matérias teológicas verdades novas não as há".

Há um campo, na corrente aberta pela descompressão pombalina, que forma um esboço de novo pensamento político, confundido, mas diferente do Liberalismo. Será, na verdade, uma ideologia e uma filosofia política que entrará, mais tarde, no lugar do 
Liberalısmo. "Primeiro germinaram as idéias; os fatos e realidades vieram depois", dız Cabral de Moncada $(1949$, p. 105). O veículo será a moral, a filosofia e, sobretudo, o direito, anda presos ao direito natural. Pascoal José de Melo, lente de Coimbra, fruto da Universidade renovada, incumbe-se de demonstrar que o códıgo fundamental da monarquia portuguesa está nas Cortes:

as Cortes de Coimbra que elegeram D. João I e as de 1641 que elevaram ao trono D. João IV. Sustenta o valor dos forais, com as garantias que deram ao povo, bem como a importância do regime munıcipal e comunal. "Não é uma obra, é uma barricada contra o absolutismo e o estado politico e civil da nação portuguesa dessa época (...) Esta obra tem para Portugal a mesma força revolucionária do Espírito das Leis de Montesquieu" (D'ARRIAGA, 1886 , t. I, v. 1, p. 415). Outros juristas e filósofos se seguem, sem chegar, embora admitındo-a implicitamente, à monarquia constitucional e parlamentar. Ribeiro dos Santos não citaria, mais tarde, nem Rousseau, nem Montesquieu.

Contrapunha as leis do rei às leis do Reino, num apelo irrevelado às Cortes. Depois de 1789, viriam os afrancesados, com leituras severamente proibidas no Reino. Predominava sobre esses padrōes, a presença de Bentham, o Rousseau dos portugueses. Desta safra vırá maıs tarde Silvestre Pınheıro Ferreira (1769-1846), embora mais tardia sua presença. Outro lente de CoImbra, Antônı Soares Barbosa, segue na timıda trilha aberta por Verney, mas não aceita a idéia do direito natural absoluto, no modelo de Justiniano, Hobbes, Pufendorf e Rousseau. Acentua o valor da liberdade, como base das ciências morais, sem permitir-se vinculá-la à política. Não esconde a igualdade natural e jurídica dos homens, rejeitando a teoria do contrato social.
Antes de Vicente Ferrer (1798-1886), o sistematizador máximo do Liberalismo português, Joaquim José Rodrigues de Brito, também lente em Coimbra, num livro de 1804 , procura renovar o direito natural, valorizando o bem-estar material, moral e intelectual como o fim da socıedade. Em reação ao pombalismo, entram em Portugal, ainda no fim do século XVIII, as idéias de Adam Smith. Daí por diante se abrirá o caminho da mudança em Portugal, dentro da pauta pombalına, com acento na renovação nacıonal e não nos direıtos do homem. $O$ Estado será o objeto da reforma e, por vıa dele, nas relações com a sociedade.

Porque Pombal desarticulou a estrutura jesuítıca, rompendo a Imobilidade, seu nome vinculou-se ao Liberalısmo. A tese, que prosperou em muitas instâncias, esclarece o que, em Portugal e no Brasil, mass tarde se entendeu que fosse o Luberalismo. Liberalısmo no qual a nota tônica descansa sobre a reforma do Estado, eventualmente na origem popular popular, em termos - do poder. Oliveira Martins afirma que o Portugal pombalıno "era um falso Portugal de importação, nas idéias, nas instituições, nos homens". O dinheiro do Brasil dava para tudo: dava para sobrepor ao Portugal embalsamado um Portugal postiço. Por essa via, pelas fronteiras e pela alfândega, no contágio ideológico e na recepção da filosofia política, germinou a futura transformação da estrutura de poder. "Por isso mesmo que a máquina era construida com materiais da Europa, onde uma revolução se realizava nas idéias, os homens de fora vieram lançar no torrão português a semente das revoluções futuras." (OLIVEIRA MARTINS e PEREIRA, 1942, t. II, p. 207-9.)

$O$ desmantalemento do Santo Ofício, a reforma do ensino, a aproximação com a Europa seriam os pilares do futuro 
Liberalismo. $O$ assunto assumiu as proporçōes de uma polêmica. Contra a mitologia do precedente protestou Camilo, por ocasıão do centenáno, destacando a contradição entre democracia e o estadista do poder absoluto. "Só à falta de um nome pomposo e aureolado de fulgores sinistros em que pudesse encarar a idéia do bem, a democracia, que näo sabe fazer andar uma idéia levantada e grande sem a encostar às muletas dum titulo, adotou um marquês - o tipo emblemático do poder absoluto que, a um tempo, triturava fidalguia e ralé (...)." (CASTELO BRANCO apUd FALCON, 1982.)

O certo é que a irrupção pombalına rearticulou o Estado, aproximando-o de setores novos, rompendo com a aliança senão hegemonia - eclesiástica, numa transação com a burguesia mercantıl, com o enfraquecimento do setor mais conservador da aristocracia, liquidando as diferenças entre cristăos-novos e cristãos-velhos. Por aí entraria em Portugal o Liberalısmo, com a Revolução de 1820 e por ai se fixaria o modelo liberal do Brasil, oficial e dirigido do alto, como apêndice do Estado.

Liberalismo, pela sua origem, irrealızável, senão com a condição, historicamente impossivel, de desarticular o aparelhamento estatal, para convertê-lo em guarda dos direitos individuass, não de seu tutor, mas sim de seu algoz.

No Tratado de Direito Natural, obra de 1768 , encontra-se a súmula da filosofia política portuguesa, dentro da qual, com o limite ideológıco, articula-se o pensamento político. $O$ livro é dedicado a Pombal e aprova a política do ministro, ao sobrepor o poder civil ao eclesiástico, em convivência, porém, com o "absolutismo ilustrado". Sustenta a superioridade do Concílio sobre o papa. Nega a jurisdição temporal do papa:
"Se o papa tivesse jurisdição temporal direta ou indireta sobre os reis, seguir-se-ia que o poder temporal do rei não era supremo na terra e que reconhecia outro superior que näo fosse Deus"(GONZAGA, 1957, p. 89). Não há a intermedıação popular no poder, que emana diretamente de Deus. (Idem, p. 101.). $O$ direito de resistência não existe, em nenhuma cırcunstâncıa. "Viveriamos sempre em uma continuada discórdia, se por qualquer injustiça houvesse o povo de se armar contra o soberano para o castigar $e$ depor" (Idem, p. 103). "A minha opiniấo é que o rel não pode ser de forma nenhuma subordinado ao povo; e por isso, ainda que o rei governe mal e cometa algum delito, nem por isso o povo se pode armar de castigos contra ele. Já mostramos que os delitos do rei não podem ter outro juiz senâo a Deus, de que se segue que como o povo não pode julgar as ações dele, o não pode também depor, pois que a deposição é um ato de conhecimento e por consequência de superioridadt." (Idem, p. 106.)

À futura audácia de Pascoal José de Melo, que, sem contestar o absolutismo, resgatava a histónca origem eletiva dos reıs, se contrapõe a doutrına oficial. Mesmo que eletivo o reı, a transferência do poder será irrevogável - este o leıto em que pisariam os pensadores seguintes. "Todas as vezes pois que o povo elege a algum para seu soberano e este aceita, adquire logo o império de tal forma, que nem o mesmo povo lho poderá mais tirar nem ele carecerá de confirmação alguma, inda a do mesmo papa" (Idem, p. 111). O rei legisla, julga, tributa, com o domínio iminente sobre todos os bens dos vassalos, em regime patrimonialista. "A obrigaçāo de se obedecer nasce da superioridade de quem manda e não do consentimento do súdito." Mais: o príncipe não se obriga com suas leis. "Logo, näo podemos
O certo é que a irrupção pombalina rearticulou o Estado (...). Por af entraria em Portugal o Liberalismo, com a Revoluçāo de 1820 e por af se fixaria 0 modelo liberal do Brasil, oficial e dirigido do alto, como apêndice do Estado. 
por obrigação no rel, nascida de sua própria lel, pois que ele não pode exigur a si mesmo a sua obsenvação."

(GONZAGA, 1957, p. 143-4)

As reformas pombalınas ırradram-se no Brasil, entre os letrados, alguns egressos de Colmbra. Houve um arremedo do Século das Luzes, crítıco, sem refletır com energia a crise do colonialismo. " $O$ nosso - depõe Antônıo Cândido - foi um Século das Luzes dominantemente beato, escolástico, inquisttorial; mas elas se manifestaram nas concepções e no esforço reformador de certos intelectuais e administradores, enquadrados pelo despotismo relatwamente esclarecido de Pombal Seja qual for o juizo sobre este, a sua ação fol decisiva e benéfica para o Brasil, favorecendo atıtudes mentals evoluidas, que incrementarlam o desejo de saber, a adoçāo de novos pontos de vtsta na literatura e na ciêncta, certa reação contra a turanta intelectual do clero e, finalmente, o nativismo " (MELLO E SOUZA, 1981, v. 1, p. 69)

As expressões escritas maiores são, segundo o mesmo autor, o Uraguai (1769), de Basílıo da Gama, de feıção antijesuítica, $O$ Desertor (1771), de Silva Alvarenga, com o destaque posto na reforma intelectual e $\mathbf{O}$ Reino da Estupidez (1785), de combate à Viradeira, de D Marıa I (m. 1816; regêncıa de D João, depoıs o VI, em 1799). Era uma literatura integrada na portuguesa, embora o círculo de letrados que a produziu e o círculo maior ao qual pertenceram seja atraído pela inquie tação colonial, com o vínculo liberal que a marcará, Liberalısmo só por transação ajustado ao Liberalısmo oficial que se expandirá, dentro do Estado, como reflexo da Revolução Portuguesa de 1820.

As manıfestações literárias de nossa Época das Luzes não dão idéra certa acerca do nivel educacional da população. No fim do século XVIII, a população do Brasıl seria de doss e meio milhões de habitantes, dos quats um e me1o livres, com cerca de $830 \mathrm{ml}$ brancos, os únıcos, pela ongem social, aptos a se instruírem. Em Minas Gera1s, por exemplo, em 1786, numa população de 362847 habitantes, a percentagem de escravos atıngra 47\% (HALLEWELL, 1985, p. 176/MAXWELL, 1973, p. 266).

Embora houvesse bibliotecas nos colégios, particularmente nos jesuítıcos, a impressão local de lıvros era pratıcamente nula. As bıblıotecas partıculares eram raras, embora elas denunciassem a possibilidade de obter livros proibidos de circular. Southey retratou bem a sıtuação, mostrando os limites que a cırcunstâncıa impunha ao pensamento polítıco, que, para se propagar, precısava formular-se por escrito, como por escrito também alcançava a audiêncıa da metrópole. "Outra prova de miserável ıgnorância fou não se tolerar no Brastl tıpografia alguma antes da transmigração da corte. Achava-se a grande massa do povo no mesmo estado como se nunca se houvesse inventado a imprensa. Havia muttos comerciantes abastados que não sabıam ler, e dificil era achar jovens habilitados para caixeiros e guarda-livros. Nem era raro um opulento sertanejo encomendar a algum de seus vizinhos que de qualquer porto de mar lhe trouxesse um português de bons costumes que soubesse ler e escrever, para casar-lhe com a filha. Contudo, havia, na maior parte das povoações, escolas públicas de primetras letras, tomando os respectivos mestres bem como os de latim, na maior parte das vilas, o titulo de professores régios, instituição singularmente incongruente com esse sistema cego que protbia a imprensa. Os que tinham aprendido a ler poucas ocasiões encontravam de satisfazer o desejo de alargar os seus conhecimentos (se acaso o possuiam), tão raros eram os livros. Desde a expulsão dos jesuitas, nenhuma 
das religiōes fizera timbre da sua

literatura, nem do seu amor ao Estado, $e$ as livrarias deixadas por aqueles padres tinham quase inteiramente desaparecido num pais onde, não sendo conservados com cuidado, depressa são os lïros destruidos pelos insetos. "(SOUTHEY, 1965, v. 6, p. 365-6.)

$O$ quadro traçado por um contemporâneo, Luis dos Santos Vilhena (m. 1814), confirma o desprezo pela instrução. No tempo dos jesuítas, havia nos colégios sete classes, nas quais "se gastava meia vida de um estudante com o simples estudo de gramática latina".

Com o sistema dos professores públicos, depois instituídos, houve carência de recursos para manter a rede de ensino. $O$ respeito ao ensino era mínimo, com a prisão dos estudantes melhor aproveitados para servirem como soldados: "não é, declara a propósito desses atos de tirania, das menores desgraças viver em colônias longe do soberano, porque nelas a lei que de ordinário se observa é a vontade do que mais pode". "Ser professor, e não ser nada, é tudo o mesmo" (VILHENA, 1969 , v. 1, p. 273 - segs.). 0 traço mais saliente da reforma cultural não será, entretanto, a produção de alguns escritores, nem a da disseminação do ensino, mas o de uma escola de elites. $O$ bispo Azeredo Coutinho (J.J. da Cunha Azeredo Coutinho - 1742-1821) fundou o Seminário de Olinda, que introduzia no Brasil o novo ensino, divulgado por Verney e protegido pelo marquês de Pombal, centralizando a instrução da capitania, seminário "logo considerado o melhor colégio de instrução secundária no Brasil"'(OLIVEIRA LIMA, 1975, p. 216).

Não tardaria em se manifestar, pelos padres aí educađos, a mudança da mentalidade colonial até então modorrentamente imóvel.

\section{Os Liberalismos}

Há, na base que se constitui o eixo sobre o qual gravitará o pensamento político brasileiro, o encontro de duas rotas. Caberá indagar quals eram essas correntes e qual a natureza dessa combinação sobre a qual repousa a pergunta acerca de um pensamento político autônomo e dinamicamente centrado no País. $O$ momento e o processo da junção será a independência. " $A$ independência, tal como se operou, teve aliás o caráter de uma transação entre o elemento nacional mais avançado, que preferiria substituir a velha supremacia portuguesa por um regime republicano segundo o adotado nas outras colônias americanas, por esse tempo emancipadas, e o elemento reacionário, que era o lusitano, contrário a um desfecho equivalente, no seu entender, a uma felonia da primitiva possessão e a um desastre financeiro e econômico da outrora metrópole. A referida transação estabeleceu-se sobre a base da permanência da dinastia de Bragança, personificada no seu rebento capital, à frente de um império constitucional e democrático, cujo soberano se dizia proclamado 'pela graça de Deus e pela unânime aclamação dos povos' a um tempo ungido do Senhor e escolhido pela vontade popular." (OLIVEIRA LIMA, 1947, p. 11.)

A transação, de que natureza for? Consagrou a ideologia liberal, preparada pela filosofia política, ou foi uma mera contemporização, uma conciliação, que conserva $o$ antigo com verniz novo? Permaneceu intocado, na junção, um dos elementos, que iria ser represado, sem nunca se expandir, uma vez que seu desenvolvimento dependeria de nova estrutura do Estado? Na mistura de dois liberalismos, qual será o Liberalismo, o da transação, expresso na dissolução da Constituinte de 1823 
e na Constıtuição de 1824, ou o outro, que ficana submerso e irrealizado, quando sua realızação era a condição necessária para a sujeração do passado?

O elemento nacional compõe a corrente emancipacionista, larvarmente natıvista, preso à crise do sistema colonial. Forma um ciclo que se manıfesta, conı intensıdade variável, nos movimentos de 1789 (Inconfidência Mine1ra), na repressão do Rio de Janeiro (1794), na Revolução dos Alfarates da Bahia, de 1798, irradiando-se depois em 1817, 1824, em 1831, nas insurreıções regenciais, em 1842 e eventualmente da Prateira, em 1848. Este é um padrão polítıco, que se contrapõe e contende com a reação e contemporızação ao Liberalismo da Revolução Portuguesa de 1820 , o qual, Irradiando-se no Brasil pela via da Corte, ditará o perfil polítıco da Independência. $\mathrm{O}$ elemento nacional está no sentıdo certo: não se trata de um pensamento nacional, de um pais como Nação, mas como núcleos não-homogêneos, com um projeto apenas como projeto - nacional. As cırcunstâncıas - a dissolução do sistema colonial - teriam configurado as bases de uma consciência histórica, estamental e virtualmente de classe, sem que se possa configurar uma situação revolucionária, pelo menos no seu momento inicial, pela ausência do projeto. Mas o quadro é de um conjunto de possibilidades, num processo difuso. Trata-se de uma consciência possivel (GOLDMANN, 1972, p. 7). A consciência possivel não atınge a realızação na consciência real. Explica-se, com isso, que a filosofia política, livrescamente adotada, e a 1deologia, perfilhada dogmaticamente, não se convertam na práxis, no efetivo fazer, realizar e transformar, mas em verbalismo desligado da realidade.

A crise do sistema colonial coincide com o processo de ruptura do absolutismo. Em torno de 1776, a independência das colônias britânicas coincide com o fim do consulado pombalino. "Do consulado pombalino $\grave{a}$ vinda do Principe Regente para a América transita-se nas águas revoltas da crise geral do Antigo Regime e do sistema de colonização mercantilista." (NOVAIS, 1985, p. 11.)

A crise gerou forças contraditórias: de um lado, o neopombalısmo, que se articula na transação promovida pela Corte, de outro lado, pelas tentativas de ruptura, na escala colonıal autônoma. $O$ fato que estava em questão era a penetração mundial do capitalısmo industrial, que rompia os moldes do mercantilısmo, sem que Portugal, sentindo o grave inconveniente da Invasão, pudesse dispensar, em termos politıcos, a alıança do pais-líder da transformação, a Inglaterra. Para as colônias, o regime de trocas, sob o ponto de vista do produtor, dispensava o entreposto colonizador, mero intermediário, fiscalista, no velho regime da economia de trânsito. "Fixemos depõe Fernando Novals - o mecantsmo básico do regime comercial, eixo do sistema da colonização da época mercantilista. $O$ 'exclusivo' metropolitano do comércio colonial consiste em suma na reforma do mercado das colônias para a metrópole, isto é, para a burguesia comercial metropolitana. Este $o$ mecanismo fundamental, gerador de lucros excedentes, lucros coloniais; através dele, a economia central metropolitana incorporava $o$ sobreproduto das economias coloniais ancilares. Efetivamente, detendo a exclusividade da compra dos produtos coloniais, os mercadores da mãe-pátria podiam deprimir na colônia seus preços até ao nivel abaixo do qual seria impossivel a continuação do processo produtivo, isto $\dot{e}$, tendencialmente ao nível dos custos de produção; a revenda 
na metrópole, onde dispunham da exclusividade da oferta, garantia-lhes sobrelucros por dois lados - na compra e na venda. Promovia-se, assim, de um lado, uma transferência de renda real da colônia para a metrópole, bem como a concentração desses capitais na camada empresária ligada ao comércio ultramarino." (NOVAIS, 1985, p. 89.)

Os historiadores e os contemporâneos, no fim do século XVIII, mostram, com toda a clareza, a inquietaçáo colonial, os apertos da camada produtiva, da qual viriam os protestos contra a ordem colonial. Tudo estava em crise, o açúcar, 0 algodão, o ouro, e, mass tarde, as culturas emergentes. Sufocavam-nos o regime colonial, com os monopólıos e estancos, o sistema de trocas, e, devorando tudo, fiscalismo predatório, que compensana a produção reprimida.

"Cumpre advertir - nota o circunspecto Varnhagen - que todos os artigos de produção do país estavam tão sobrecarregados de direitos, e estes subdivididos de um modo tal, que nem mesmo o fisco sabia bem quanto arrecadava, nem os produtores quanto tão complexamente pagavam." (VARNHAGEN, 1956, v. 5, p. 62.)

A mão-de-obra escrava, tributada e encarecida, era aplicada em produtos de exportação, geradores de lucros imediatos, com o descuido da lavoura de subsistência, com crises de fome da população desprivilegiada. Para acudır ao mal-estar, visível e expansivo, a estrutura repressiva exacerbou-se. "Grandes abusos havia que alto clamavam por emenda. Até agora tinham exercido os governadores autoridade despótica nas suas capitanias, não reguladas por leis, não refreados pelos costumes, não assoberbados pela opiniāo pública, por nenhuma responsabilidade contidos. Absolutos como outros tantos paxás, levavam aos sub-déspotas turcos a vantagem de ter perfeitamente seguras as cabeças. Nos antigos tempos, quando para o serviço do Estado se carecia de alguma contribuição nova, era a matéria proposta pelo governador ao senado da cámara, e resolvida com o assentimento do povo: este direito cortinuaram as câmaras e o povo a exercê-lo até que em Portugal se apagaram os últimos vestigios de bom governo, estendendo-se entฮ̄o ao Brasil o sistema arbitráno sob o qual definhava a mãe-pátria. Tomou o governo colonial caráter meramente militar, sendo as câmaras convidadas ñ̃o a consultar, mas a obedecer. "(SOUTHEY, 1965, v. 6, p. 360-1.)

A introdução das tropas regulares enrijeceu o sistema de subordınação, com os recrutamentos forçados, que abrangiam, como se viu, os estudantes, perturbando o ensino. "Outro agravo prossegue o mesmo histonador - vinha do modo por que se recrutavam as tropas regulares. o principio era dar cada familia que tivesse dois ou mais filhos solteiros, um para o exército, e serem presos para soldados todos os individuos de má nota entre dezesseis e sessenta anos de idade." (Idem, p. 363.)

É claro que a má nota corria por conta da vontade dos recrutadores, com o beneplácito, em últıma instância, dos governadores.

Os comerciantes, a burguesia comercial, que depois se ligara ao elemento reacionário na transação da Independência, portugueses pela origem e pelos interesses, aliam-se ao poder, depois integrando-se na Corte. Eles serão o este1o do Liberalısmo oficial, transmigrado de Portugal. $O$ elemento nacional, o dos produtores reprimidos, com seus intelectuais - padres e letrados - seguirá outro rumo. É hora de insistir na quebra da falácia do reacionarismo dos produtores, da propriedade agrícola, vinculada com os mineradores ao repúdio ao sistema colonial. Uma testemunha da época,
Os comerciantes, a burguesia comercial, que depois se ligara ao elemento reacionário na transação da Independência, portugueses pela origem e pelos interesses, aliam-se ao poder, depois integrando-se na Corte. Eles serão o esteio do Liberalismo oficial, transmigrado de Portugal. 
Vılhena, documenta a ascendêncıa, ao lado dos administradores nomeados pela Coroa, dos comerciantes. Nota que "tendo seus pats vindo não há multos anos para o Brasll, para serem calxeiros, quando twessem capacidade para o ser, porque a fortuna lhes fol propicia, $e$ juntaram grandes cabedais, culdam seus filhos, que o imperador da China é indigno de ser seu criado: 'Sabe continua - todo o mundo comerciante, que a praça da Bahia é uma das mals comerciosas das colonnas portuguesas, e que o seu comércto, bem a pesar das nações estrangetras, é somente privattvo aos vassalos da Coroa de Portugal, sem que o possam manter, ou girar à exportação, mais do que para esse Remo, e algumas das suas colontas, ou senhorios, como sejam todas as costas, e interior do Brassl, ilhas dos Açores, e ainda Cabo Verde, Reino de Angola, $e$ Benguela, Moçambique, tha de S. Tomé e Princtpe, além dos portos no golfo, e costas de Gutné. Compõem-se o corpo dos comerciantes existentes na Bahta de cento e sessenta e quatro homens (..) e que alguns destes comerciam só com seu nome, e com cabedals de personagens a quem seria menos decente o saber-se que comerciam (. . ) Nem todos os compreendidos naquele número são matriculados, mas sim chamados comissános(. .)"(VILHENA, 1969, v 1, p. 52, 56.)

E os soberbos senhores de engenhos, os agricultores, os que eram reputados como os que mandavam, que eram eles? Que eram os mineradores ao lado dos comerciantes de ouro e diamantes e dos poderosos contratadores, espécie de funcionários do Estado patrimonalısta? Entre os proprietános de terras, os que não fossem também comerciantes, qualıdade a última que os aproxımava da arıstocracia colonial, estamentalizando-os, sofnam todo o peso do sistema colonial.
"Grandes fortunas - ao deles tratar, nota Oliveira Lima - não existiam. o que havia eram extensas propriedades, proporctonalmente de escassa remuneração por não ocorrerem, com o sistema do monopólio mercanttl, oportuntdades de especulação. Allás, as grandes fortunas são por via de regra antes industriais e comerciais do que agricolas os lucros agricolas costumam ser moderados, sendo precisas circunstâncias excepcionais (. . .) para certos artigos darem elevados proventos. Os latifúndıos colonats apresentavam-se, em larga proporção, baldios e não podıam, nestas condições, assegurar um rendımento sequer sufictente e estável. $O$ número dos ricos andava limitado, graças à divisão da propriedade, a não ser pelo resultado do próprio trabalho $e$ felıcıdade ora, com a obrıgação do esforço individual, maıor ou menor, cessava a prımeira condlção de uma artstocracia do lazer "(OLIVEIRA LIMA, 1947, p. 33.)

Vilhena, em tintas mass vivas, descreve a relativa desvalia dos agnicultores e senhores de engenho, comparados com os comerciantes, vinculados ao regıme colonıal e à admınistração pública, poderosa e onipotente. "Venho de dizer que um pais extensissimo, fecundo por natureza, e riquissimo, è habitado por colonos, poucos em número, a mator parte potres, e muitos deles famintos (...) Os senhores de engenho nada têm, a maloria deles, que a aparêncta de ncos; pots que a maior parte das safras dos seus engenhos, descritos na Carta $V$, não chegam para satisfazerem aos comerciantes assistentes. Todo o mats povo, à exceção dos comerciantes e alguns lavradores aparatosos, como os senhores de engenho, é uma congregação de pobres, ..." (VILHENA, 1969, v. 3, p. 914-5). Mas o cronista não esquece o estılo de vida: a "aparência de ricos" e os "lavradores 
aparatosos". Os senhores de engenho são "soberbos de ordinário, e tão pagos da sua glória vã, que julgam nada se pode comparar com eles, logo que se vêem dentro nas suas terras, rodeados de seus escravos, bajulados de seus rendeiros, servidos de seus mulatos, e recriados nos seus cavalos de estrebaria (...) Esta é pois a glóna dos senhores de engenho, e para maior auge dela, têm na cidade casas próprias, ou alugadas; cumpre muito que tenham cocheira, atnda que não haja sege, o que suprem asseadas cadeiras, que todos têm, em que saem acompanhados de seus lacaios mulatos, ornados de fardamentos asseados"(VILHENA, 1969, v. 1, p. 185).

A consciência da exploração do sistema colonial se expressa na ideologia liberal, que é, ao mesmo tempo, uma filosofia política. $O$ pensamento político - tal como o conceituamos neste ensaio, como integrado na práxis tem conexẫo necessára com $o$ Liberalismo? Por que, sem exame crítico, identıficar a ınassımılação, que não chegou a criar uma consciência nacional, com um tipo cultural? Será pobre e insuficiente a explıcação do contágı ideológico. $\mathrm{O}$ contágio ideológıco traduz uma situação estrutural que permite, facilita e o estımula. $O$ vínculo deve ser reexaminado, para que se entenda a aproprração, que depors de 1820 se fará, desse legado, para que a consciência possivel não se converta em consciência real. Os atores e 1deólogos não mencionam a revolução, numa conjuntura, embora não-nacional, na realidade revolucionána. "Nessa crise, que expressa a desagregação de todo um regime e de uma colonização, é gerado o espirito revolucionário. Espirito revolucionário que, de resto, não é alimentado apenas por leituras importadas da Europa ou da América Inglesa." (MOTA, 1979, p. 32.)
Leituras importadas, seletıvamente adotadas e rejeitadas, não para a definıção, mas para um esboço de pensamento. O projeto, a utopia revolucıonária, define-se com vacılação, transitando, ma1s tarde, pela transação de 22. Há uma maneıra ırada e uma maneıra suave de construir a ponte - a ponte imagınária que será a moldura da futura Nação. Ambas, a maneıra rrada e a maneıra suave, não coincıdem, entretanto, com o molde imposto pela Corte e que estará na Constıtuç̧ão de 1824. Talvez um acidente explique muita coisa A vinda da Corte, em 1808 , tenha interrompido uma jornada, rompendo a autonomia de um processo e interiorizando a metrópole (SILVA DIAS, 1972, p. 165) O fato, entretanto, como prova $o$ desenvolvimento do século $\mathrm{XIX}$, é que o rumo do elemento nacional, embora transacionado, permaneceu vivo, apesar de não-dominante. Ele atua, na prática, no cerne do pensamento polítıco, com a ırrealızada superação Irrompe, no curso da históna, nos dois séculos, na dobra de todas as crises de sistema e de governo. A conjectura de um velo inesgotado permanece, portanto, atual e inexplicada, truncando o desenvolvimento de um pensamento político nacional, dinamicamente autônomo e capaz de levar a um estágıo pós-liberal.

A emancıpação intelectual do universo português, o acanhado universo mental metropolitano, ocorre gradativamente, no penoso esforço de juntar idé1as européras $e$, muitas vezes, proibidas. Os conspiradores mineiros, homens de prol, proprietános e senhores de clientelas, não mais admitiam captar os favores oficials para atenuar a carga do sistema colonial. $O$ escopo era a separação da metrópole e a ơrganızação de um Estado, republicano por necessidade. A 
justıficação ideológica vinha pela via francesa, e, pela via francesa, se consolidava o modelo americano. Importância fundamental exercerıa a obra de Raynal, a Histoire Philosophique et Politique des Etablissements e du Commerce des Européens dans les Deux Indes, publicada onginariamente em 1770 , con! muitas reimpressర̃es sucessivas. $O$ volume era encontrado nas bibliotecas do tempo, as apreendidas e as que se salvaram (FRIEIRO, 1981, p. 40/ BURNS, 1971, p. 9/MAXWELL, 1973, p. 126). Circulava entre os conspiradores o Recueil des Loix Constitutives des Etats-Unis de l'Amérique, publicado em Flladélfia em 1778, que continha Os Artıgos da Confederação, mais as constıtuıções da Pensilvânıa, New Jersey, Delaware, Maryland, Virginia, as Carolınas e Massachussets (MAXWELL, 1973, p. 126). O padrão confederativo, vitonoso nos Estados Unidos, inscientes os conspiradores de suas deficiências, por carecerem de informaçōes mais recentes, parecia-lhes viável, cogitando-se de uma unıão com São Paulo e Rio de Janeíro, sem a idéra nacional. $O$ regime revigorava, por outros meios, $o$ munıcipalısmo, com suas Câmaras, que, refundidas em cada cidade, se subordinariam a um Parlamento Principal. Coexistente ao corte do vínculo com a metrópole, colocava-se o problema da representação, o problema, afinal, do governo. Ao deliberarem pela abolição do exército permanente, em favor da mulícia popular, reservavam o comando da força em favor dos principals. Para evitar a hostilidade dos escravos, numa capitania onde eles constıtuíam a maioria da população, fixou-se o compromisso de libertar os mulatos e negros nascidos no Faís, como expediente de segurança do movimento (MAXWELL, 1973, p. 134). “ $A$ conspiração de Minas foi fundamentalmente um movimento feito por oligarcas no interesse dos oligarcas, no qual o nome do povo se evocou como mera justificaçẫo." (Idem, p. 139.)

Era necessário, ao lado do sistema representativo a ser adotado, que se fixassem os direitos dos cidadãos, em movimento correla to à liberação do absolutısmo metropolitano. Um pacto entre 1guass, baseado num catálogo de direitos, dava a nota necessanamente liberal. Nenhum constrangimento há entre liberalismo e escravidão, certo que o novo aparelho estatal protege os direstos, entre os quass, e, no caso, sobretudo, o de propriedade, abrangente dos escravos. $O$ caminho da revolução passava, de outro lado, uma vez que se reorganizana o Estado, pela via contratual · pela entrega do poder, que está nos revolucionários, a uma entıdade a eles supenor e deles dependente. Explıca-se, desta sorte, a popularidade de Rousseau e dos enciclopedistas, tudo pelo mendiano de Paris. A filosofia política reınante portuguesa sustentava a origem divina e imediata do poder, e, como se notou, repelıa a idéia de resistêncra, anda que criminoso ou tırano o rel. Não se mostrava adversa, de acordo com os pensadores do direito natural adotado em Coımbra, à admissão de que a sociedade civil ou cidade unia os homens "por pactos expressos ou tácitos, para haverem de gozar uma vida mais segura e mais tranquila" (GONZAGA, 1957 , p. 91). O pacto era o pacto de sujeıção, irretratável e irrevogável. Por esta porta entraria, estimulada por Rousseau, uma revisão, em favor do pacto de associação. É de ver, entretanto, que, para aceitar o pacto, negando a igualdade, era necessário um Liberalismo mais consistente: 0 que estava na Declaração de Independência, depois no Direito dos Homens, corporificado na filosofia política de Locke, não de Rousseau, com sua direção coletivista. 
Igualdade, portanto, em termos: no modelo liberal e não no modelo democrático. Embora francesas as influências - vindas da língua francesa o quadro mental percutirá o Liberalismo de Locke, e de Adam Smith, conhecido e, sem que se tenha verificado, traduzido por um dos inconfidentes.

A sugerência, alimentada pelas leituras, traça um modelo suave de Liberalismo, mais tarde, porque Liberalismo, reputado "radical", confundido ao Liberalismo rrado. A linha de pensamento obedece à inspiração de Locke, que se filtra em todo o pensamento do século XVIII, inclusive em Rousseau (DERATHE, 1979, p. 116 - segs.). Duas proposições, ambas necessárias ao Estado a contruir, ganham relevo. 0 Estado não cria a propriedade, mas é criado para protegê-la (LOCKE, 1952, §§ 124, 134). No conceito de "propriedade", vinculada ao trabalho, compreende-se " $a$ vida, a liberdade e a possessão", o conjunto dos direitos naturais e não unicamente terras e bens (LOCKE, 1952, §§ 123,87/ GOUGH, 1974, p. 96). O outro tópico define o governo, baseado no consentimento, como agente da confiança (trust), o que permite ḋ sociedade, em defesa própria, resistir ao rei (LOCKE, 1952, § 233/GOUGH, 1974, p. 154 - segs./DUNN, 1984, p. 54). Com o trust, não tem lugar o Estado patrimonialista. A presença de expressóes das camadas populares tornou atraente, ao lado desse Liberalismo, uma linha revolucionária, inspirada em Rousseau e Mably. A fisionomia suave do Liberalismo será a de Voltaire - se é que Voltaire foi um liberal -e Montesquieu. 0 Reformismo, que descende de Pombal, do mercantilismo ilustrado (NOVAIS, 1985 , p. 230), ao qual se filia José Bonifácio até a presença, ainda que tímida, de Adam Smith, nas reflexoes de Azeredo Coutinho, por exemplo (HOLANDA, 1966, p. 31).
O Liberalismo irado terá sua expressão no Norte. Entre a Bahia e Minas Gerais estará o Rio de Janeiro, cuja presença conjuratória se limitará à descoberta de leituras proibidas e havidas como revolucionárias (LACOMBE, 1970, t. I, v. 20, p. 406 - segs.). Para o oficialısmo, a discussão das novas idéias nenhuma pertinência tinha com a realidade, na qual não identıficava a crise do sistema colonial, sequer de seu arcabouço mental. Tudo não passava da difusão, segundo uma voz do quadro dirigente, dos "abomináveis principios franceses", precedente das "ideias exóticas $e$ alienigenas" de nosso tempo (VARNHAGEN, 1956, p. 23). A chamada Inconfidência Bahiana de 1798 traz a contribuição democrátıca, cujas bases, compostas dos setores desprivilegiados da sociedaaie, sentiam que poderiam tirar benefícios da quebra do sistema. Enquanto em Minas se encontrou um expediente manipulatório, na Bahia o elemento popular encontra, embora em mínimas prcporçōes, a voz jacobina. Desta vez não havia ambiguidade acerca da escravidão: todos seriam livres. Havia, na sociedade brasileira, uma insatisfação de pardos e artesãos, discrimınados na sociedade, que veriam, como possível, uma aliança com os escravos, num meio onde apenas um terço da população era branca. A inquietação foi detectada desde 1792 , por um arguto observador, estimulada pela revolta escrava de São Domingos (MAXWELL, 1973, p. 218 - segs.). Para a historiografia conservadora, tudo não passava do "alastramento das chamas incendiárias da revolução francesa", desta vez "com tendências mais socialistas do que politicas, como arremedo que era das cenas de horror que a França e, principalmente, a bela ilha de São Domingos acabavars de presenciar" (VARNHAGEN, 1956, p. 24). Haveria simplificação primária em caracterizar a 
conjura pelo simples contágio, como seria incorreto nela ver apenas uma luta dos homens de cor contra os brancos. sequer se escravos contra senhores. $O$ movimento descolonizador e liberal compбe, com o movimento, mass um elo do pensamento, que, mais tarde, adquirırá clareza e consıstêncıa. Nela aparece uma grande e, no futuro, influêncıa lıberal, a de Cıprıano Barata, formado em filosofia na Universidade de Coımbra, cırurgıão, propnetáno e senhor de escravos. Sem claro compromisso con? o antiescravismo, recomendava "cautela com essa canalha africana" (DIAS TAVARES, 1959, p. 21). Os conjurados se propunham, pelas alusões às leıturas estrangeıras, na ação nacıonalızada, a contestar a supremacia do reı - "poder indigno", "rei tirano" - com veemência desconhecida até então. A base do movimento se fixará em concretas reıvındicações. o comércio livre, liberto

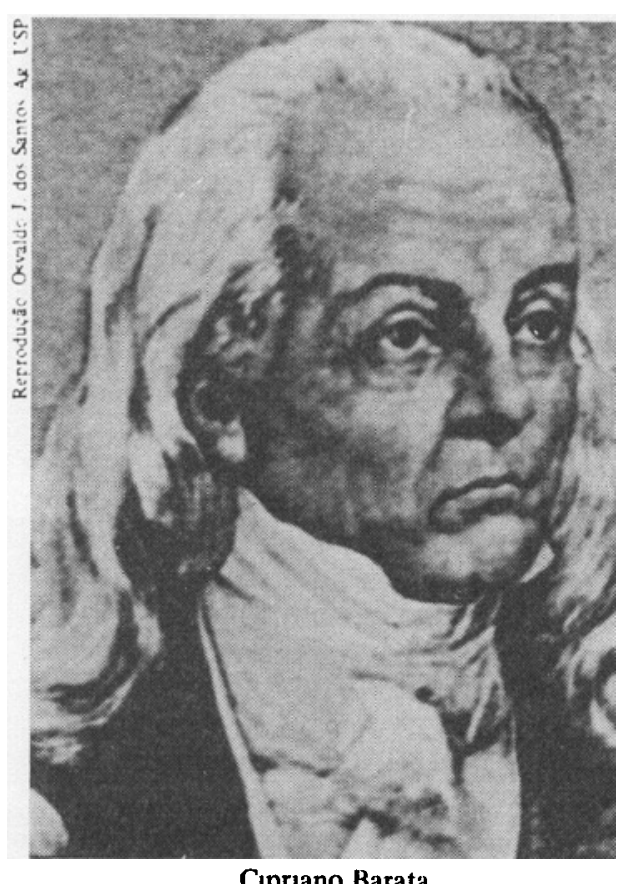

do monopólıo colonial português, e, sobretudo, os senhores de terras e de engenho, que, "além do monopólio, sofriam a exploração do capital usurário dos comerciantes portugueses, que. emprestavam dinheiro ou forneciam escravos e roupas em troca de colheitas (açucar, fumo e algodão)" (DIAS TAVARES, 1959, p. 24). No que concerne ao comércio livre, lembre-se que o inspirador era Adam Śmith, lido pelc futuro visconde de Carru, como lido fora pelos inconfidentes mineıros. $\mathrm{O}$ movimento nada tinha de socialista, numa paródıa da conspiração dos iguais de Grac chus Babeuf. $\mathrm{O}$ extremo limite das reıvindıcações repousa na ıgualdade de direitos para todos, o que afasta qualquer precocidade socialista. $\mathrm{Na}$ definitıva opınião de Luis Henrique Dias Tavares: "As aspiraçōes sociais dos revolucionários de 1798 eram condicionadas pelas relações existentes numa sociedade escravista (.. .) Sentiam o preconceito da cor e as restriçōes injustas aos negros e pardos, mesmo aos livres, mesmo aos suboficiais das milicias ou das linhas. Todavia, a revolta contra essas inibiçōes sociais e de cor eram dirigidas especificamente contra $o$ poder luso. Os revolucionários não se erguiam - mesmo os escravos, libertos ou filhos de escravos - contra os latifundiários escravistas, exploradores diretos do trabalho escravo. Não os vendo como inimigos, o que é explicável, dacias as condições de uma colônia portuguesa do século XVIII e à própria natureza do movimento, - basicamente republicano e de libertação responsabilizavam a condiçẫo colonial pelas injustiças e perseguições que sofriam"(DIAS TAVARES, 1959, p. 28)

Os "abomináveis principios franceses"'(Rodrigo de Sousa Coutınho) entram num rol de fontes gerais e de fontes vinculadas ao movimento. As fontes gerais são as do século, 
contrabandeadas em Minas, no Rio, na Bahia, em Pernambuco: Raynal, os enciclopedistas, Montesquieu, Condillac, Mably, além do popularíssimo Voltaire. Rousseau circulava na Bahia, em tradução portuguesa, não o Rousseau de $O$ Contrato Social, mas o Rousseau da novela Júlia ou a Nova Helorsa, tradução patrocinada pela loja maçônica Cavaleiros da Luz, pela via da qual teria havido assíduo intercâmbio com a França banida e revolucionáría, não-estranha à conjura de 98 . 0 movimento encontrou expressão evitemos a dubiedade da palavra influência - em 0 Orador dos Estados Gerais de 1789, na Fala de Boissy D'Anglas e em $O$ Aviso de Petersburgo (QUEIRÓS MATTOSO, 1969, p. 12). O Orador coloca o rei dentro da doutrina do trust: ele é delegado da Nação e a ela deve prestar conta de sua conduta. $O$ Discurso de Boissy D'Anglas parece pouco pertinente à situação: trata de política internacional e da tentativa de isolar a França do mundo. 0 Aviso de Petersburgo concerne ao desprezo com que são vistos os homens da "zona tórrida" e de uma Igreja compatível com os princípios do direito da humanidade. $O$ texto tem em vista a crítica aos padres enfeudados aos poderes dominantes. Um passo de irreversivel definição doutrinária estava dado. A soberania popular conquistava a categoria de premissa necessária à emancipação. $\mathbf{O}$ governante, por consequência, não seria o rei com poderes emanados de Deus, mas contratualmente fixados, num regime republicano. Os que resistiam à ordem instituída ficavam advertidos, além disso, que deveriam contar com o princípio da igualdade, ainđa que não a igualdade social, abolicionista e democrática.

$\mathrm{Na}$ vertente que analisa a crise meramente pelo colapso do sistema colonial, a transmigração da Corte, em
1808 , cortara o vínculo emancipacionista ao pensamento liberal. 0 monopólio comercial rompia-se pela própria natureza das coisas: a Corte, a metrópole, estava no Brasil. A abertura dos portos se fazia inspirada em personagem inspirado em Adam Smith, o futuro visconde de Cairu, que, em outras circunstâncias, seria um fator desestabilizador da monarquia, como foram os conjurados de Minas e da Bahia. A ala esquerda do Liberalismo perdia sua bandeira, em favor de uma futura ala direita, que tentarıa, com êxito, metropolızar a colônı. Deslıgar-se-1a, desta sorte, a causa nacional da causa liberal. Por que o esquema não operou, deixando espaço ao Liberalismo, em particular ao movimento de 1817, que traduz uma corrente indelével no pensamento polítıco brasileiro, com o signo permanente da irrealızação? De outro lado, a transmigração deixa um roteiro mais do que secular, que, passando pela Independência, dimensionará o esquema de poder, sem rupturas, em permanentes e continuadas conciliações. 0 estrangulamento da dinâmıca polítıca, da dialética filosófica, encontra seu ponto de partida em ousada hipótese. Há uma terra incógnita a percorrer, encantada pelo fascínio das origens.

A monarquia portuguesa, pelos seus intérpretes mais perspicazes, percebeu que havia, na colônia, mass do que conspiraçōes isoladas, filhas da propagação dos "abomináveis principios franceses". Em julho de 1789, um alto dignitário da Corte advertıa que não havia pelo "que recear quanto ao presente, mas sim que prevenir para o futuro"'(MOTA, 1979, p. 33). No final do século XVIII e início do XIX, depois dos acontecimentos de Minas Gerais e até a transmigração da Corte, procurou-se instituir uma política de compromisso. Luis Pinto de Sousa 
Coutinho será a voz mais significativa da proposta de mudanças, do alto de seu posto de secretário de Estado para assuntos ultramarinos. Propunha favorecer a prosperidade do Brasil, com a abolição dos monopólios e a atenuação da carga fiscal. Ousadamente, via a permanência da monarquia na transformação da colônia numa província. Suas idéias se debatiam com a oposição interna: combater o colonialismo ultramarino importava em provocar o nacionalismo na metrópole. Previa a mudança da Corte, numa transação entre o mercantilismo e o livre-comércio, num impéno luso-brasileiro, ao qual não era estranho o pensamento de José Bonifácio: "sobre o seu Brasil, - escrevia-lhe Coutinho grande será seu destino" (MAXWELL, 1973, p. 204-239). Tratava-se, num plano que discutia a própria conveniência do trabalho escravo, fonte de endividamento dos produtores diante dos comerciantes, de mudar para prevenır. Essa polítıca, uma vez que não havia mudado a equação de forças, numa colonização intenorızada, dita o procedimento do regente D. João. 0 Liberalısmo entrava na receita, como condescendência, para frustrar a mudança, esta realmente baseada no pensamento liberal. "Um ardiloso plano de resistência esboçara-se, porém, na imaginação do herdeiro da monarquia ao compreendier o perigo iminente da separação, plano que consistiu em conceder à colônia o máximo das franquias econômicas, para garantir o mínimo das cedências políticas." (OLIVEIRA LIMA, 1975, p. 228.)

Esta política, a da resistência, será posta em execução no Brasil, por D. João VI e Pedro I, numa política que imobiliza o movimento político e transaciona para que, mais tarde, se mantenha, à custa de reformas, o núcleo neopombalino do Estado. Procurava-se divorcıar, como se acentuou, a extinção do colonialismo do Liberalismo.

A atividade do pensamento político acentuou-se no ponto mais próspero da colônı. As guerras napoleônicas, a rebelıão de São Domingos, os infortúnios colonizadores nas possessðes inglesas e norte-americanas restituíram Pernambuco aos melhores dias do começo do século XVIII. O açúcar voltara a reinar, num espaço frequentado pelo imagináno nativista, ressentido com o revés dos mascates. Em 1800, pensou-se em projetar uma república sob a proteçāo francesa, na qual se comprometeram prestigiados senhores de engenho. Em 1817, chegar-se-á ao momento culminante do processo de descolonização, que conseguiu, pela primeira vez, empolgar o poder no território convulsionado (MUNIZ TAVARES, 1917). 0 motor da insurreição seriam os produtores os senhores de engenho - contra os mercadores, que, transferida a Corte, mantinham os privilégios metropolitanos. $\mathrm{O}$ ingrediente popular, alastrando-se nos escravos, dará a medida de um Liberalısmo que, como Liberalismo, não dispensa a defesa dos direitos ındividuais, embora no nível mínımo para formar a representação política. " $\mathrm{Na}$ verdade, cumpre avaliar o peso das relaçōes sociais desenvolvidas - $e$ agravadas - nas duas primeiras décadas do século passado, para que se percebam as motivações da ampla insurreição havida em 1817, aprofundada em 1821 e 1824. (. . .) Os antigos senhores rurais, que dominavam a história do periodo anterior, transmudavam-se numa 'aristocracia agrária'e, nesse sentido, procuravam afirmar-se em 1817; isto $e ́$, na qualidade de camada dominante $e$ - exceção feita de uma minoria que não conseguiu impor seus pontos de vista sobre a organização do trabalho livre escravista. (...) Na verdade, o que se 
observava era uma degradação paulatina nas relaçōes entre a aristocracia nativa e os antigos mercadores que faziam as articulaçбes do sistema colonial português. Na base de tal degradação, colocava-se o problema da propriedade: à propriedade dos 'grandes filhos do pais', contrapunham-se os 'bens dos europeus, cuja maior porção constitui a massa mais opulenta do comécio:" (MOTA, 1972, p. 20-1.)

A política de contemporização da Corte encontra os obstáculos irremovivess da administração portuguesa transplantada com a Corte em 1808 -, na verdade o Estado, exposto na centralização, no sistema tributário e no favorecimento estamental ao colonizador. Formara-se, ao lado da burocracia estamental e portuguesa, uma subcamada brasileira, discriminada no exército e na administração civil, o que, nas circunstâncias, lhe ditava a lealdade possível. 0 vínculo prenuncia uma aliança que voltará a se repetir em 1821, 1824, 1831 e 1848 (MOTA, 1972, p. 50). A revolução, capaz de atrair vultos como Antônio Carlos Ribeiro de Andrada (1773-1845) e Antônio de Moraes Silva (1757-1824), além dos padres, mal definiu seu perfil republicano, sem lograr questionar a escravidão e a participação real das classes populares. Liberalismo não significava democracia, termos que depois se iriam dissociar, em linhas claras e, em certas correntes, hostis. Os intelectuais da revolução eram os padres -60 padres e 10 frades -, ao ponto de o movimento haver sido qualificado de uma revolução de padres, o que traia a presença do Seminário de Olinda (VILAR DE CARVALHO, 1980, p. 62 - segs.). Entre eles, sobressaem João Ribeiro e o próprio cronista da revolução, monsenhor Muniz Tavares (1793-1876).

1817 marca um ponto de separação e um ponto de confluência na história do pensamento político. Daí se projetará, pelo reformismo, a transação da Independência, com a absorção da metrópole e do Estado português. Esta linha verá na revolução um equívoco, que certas concessð̃es impediriam que se repetisse. Esta é a visão cortesã e da Corte, expressa por um Varnhagen:

"Nem cremos - escreveu ele - que o Brasil perde em glórias, deixando de catalogar como tais as da insurreição de Pernaribuco de 1817, nós que fazemos votos pela integridade do império, $e$ que vimos no senhor D. Joāo VI outro imperador. E menos ainda lamentamos que não se conte desde 1817 a madureza da independência, nós que a fazemos preceder da carta régia sobre o franqueio dos portos, e por conseguinte ao mês de janeiro de 1808; e, portanto, com mais glória para o Brasil, que destarte remonta a sua emancipação colonial da Europa a uma época anterior a de todas as repúblicas continentais hispano-americanas. .."(VARNHAGEN, 1956, t. V, p. 150-1). O fim político do colonialismo, já destruído economicamente em 1808, será a independência, com o abandono da plataforma liberal, em favor da construção do império. Esta linha adotará o nome, sem conservar a coisa, não por astúcia, mas pela lımitação do princípio dentro do Estado transmigrado. De outro lado, properará o Liberalismo, na letra e no espirito, já presente em 1817, com inclinação, em alguns casos, para as idéias democráticas, sem que se toque na situação escrava. Liberalısmo nacionalista, não-popular, com a cidadania negada às "baixas camadas da sociedade" (MOTA, 1972, p. 252 segs.). Muitos revolucionários de 1817 , como Antônio Carlos, aderem à transação, que se deveria processar no interior da Assembléia Constituinte. A maior parte deles aceita o império, mas com ele
O fim político do colonialismo, já destruído economicamente em 1808, será a independência, com o abandono da plataforma liberal, em favor da construção do Império. Esta linha adotará o nome, sem conservar a coisa, não por astúcia, mas pela limitação do princípio dentro do Estado transmigrado. 
Frei Caneca: “Quem punirá as arbitrariedades do ministério e seus oficiais? Qual será o cidadão, que possa contar com a segurança da sua vida, da sua propriedade, da sua honra?"

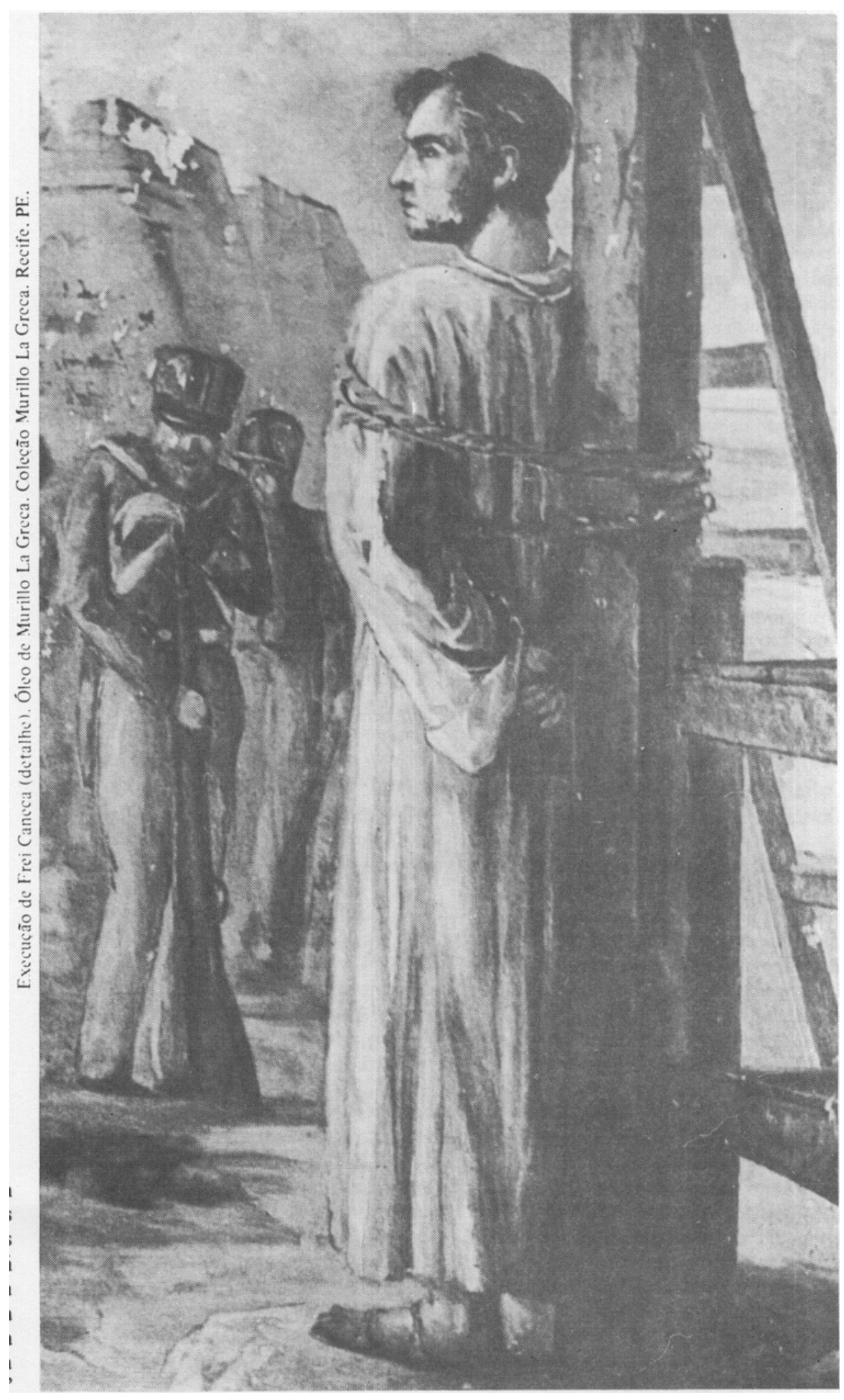


romperá quando este, ao se constituir, arquiva a intangibilidade dos direitos e a soberania nacional como fonte do poder, sem a precedência monárquica, a qual criará, dentro de si, um corpo que será o grande eleitor - o poder moderador, a representação das camadas que associaram a descolonização ao Liberalismo. Este Liberalismo será acoimado de radical, para distingui-lo da acoimadação imperial.

Cipriano Barata (1762-1838) e frei Caneca (Joaquim do Amor Divino - 1779-1825) serão os críticos do processo de desvirtuamento do Liberalismo (MONTENEGRO, 1978). Cipriano percorre o ciclo liberal completo - 1798, 1817 e 1824. Da-lhe continuidade frei Caneca que, acorde com o compromisso da Assembléia Constituinte, não aceita a outorga régia, nem o esquema andradino de Estado. Cipriano Barata, um dos deputados às Cortes de Lisboa, percebe que o absolutismo persiste apesar de 22. Em torno da Independência, depois da dissolução da Assembléia Constituinte, governará o Partido Absolutista, percepção que será comum aos liberais da época (MARINHO, 1977, p. 51). Repelem, na sua doutrinaçăo, 0 Liberalismo da restauração, que aqui entrará em revide acoimadatício "conter e dirigir" na formula de um alto conselheiro de D. João VI (OLIVEIRA LIMA, 1975, p. 266). Na defesa constante do processo que o condenou à morte pela participação na Confederação do Equador, frei Caneca traça, com clareza, a medula de seu pensamento. Nega que fosse separatista e republicano, mas afirma, de acordo com seus escritos: " $A$ soberania estava nos povos. Os povos não são herança de ninguém. Deus não quer sujeitar milhöes de seus filhos ao capricho de um só. Os reis não são emanação da divindade, são autoridades coristitucionais. (...) Os povos têm o direito de mudar a forma de governo. As Cortes são superiores ao imperador.

- Clamando-se ao soberano congresso sobre alguma lei, que dele emanar, a qual contrária seja aos interesses dos povos, se estes não forem atendidos, desfeito está o pacto; cabe-nos então reassumir nossos direitos. (. . . I O povo do Brasil deu por generosidade o trono ao imperador. $O$ governo absoluto, o maior de todos os males. . ."(FREI CANECA, 1979, p. 79-80). Percebeu Caneca, ao acompanhar os trabalhos da Assembléra Constitunte e sua dissolução, que se estava a criar "nūo um impéno constitucional, sim uma monarquta absoluta". 0 absolutısmo estava na ausêncıa de representação nacıonal, aında no grau lımitado proposto pelos liberais.

Inexistente ou inautêntica a representação nacional, perguntará. "Que barretra haverá contra os ataques que o executivo fizer aos direitos da Nação?

Quem fará suspender a propensão do executivo para a tirania? (. . .) Quem punira as arbitrariedades do ministério e seus oficiais? Qual será o cidadâo, que possa contar com a segurança da sua vida, da sua propriedade, da sua honra?" (FREI CANECA, 1979, p. 452, 454). A inspiração, em cıtaçōes explícitas, virá de Locke e Montesquieu. Combate a "cabala portuguesa", o elemento colonizador, embora interiorizado, em nome dos "homens probos, constitucionais, ricos proprietários". A Carta de 1824 não estava na "esteira dos Locks, dos Hamilton", do Espírito das Leis (Idem, p. 459-60). Pregava, coerente com o programa liberal, a rejeıção da Constituição de 24 , com a consequente dissolução do pacto social, admissivel pelo poder de resistência. "Nós queremos uma constituiçāo que afiance e sustente a nossa independência, a união das provincias, a integridade do império, a liberdade politica, a igualdade civil,

estudos AVANÇADOS 
e todos os direitos do homem em sociedade; o ministério quer que, $\grave{a}$ força de armas, aceitemos um fantasma irrnsório e ilusório da nossa segurança e felicidade. .."(Idem, p. 553). Aí estará o radicalismo, cuja essência é o Liberalismo norte-americano e europeu, socialmente conservador. $O$ que importa acentuar é que esse Lıberalısmo não pôde, em nenhum momento, compatibilizar-se com o Estado brasileıro. Os lıberais têm, com o poder, uma relação tempestuosa ou ambígua: serão potencial ou realmente sediciosos, ou, sem tocar no Estado, farão a polítıca conservadora. Esta cısão está na base do pensamento polítıco brasileıro e terá consequências que impedem o desenvolvimento, a adequação do pensar e o fazer. Melhor: de incorporar. ao fazer o pensar.

O Liberalismo não conseguı alterar a estrutura do Estado, instituindo um Estado protetor de direitos. Conseguiram os liberais, só eles, agregar camadas populares e urbanas aos seus objetivos, sempre frustradamente. $O$ ponto de dıssídıo na Assembléıa Constıtuınte será a precedêncıa do reı sobre a Constıtuição. Mesmo com o malogro do compromisso dos liberais, não prosperou sua política para um sistema republicano e federativo. Dividem-se na facção exaltada e na facção moderada. Virá a época da Cabanada no Pará, da Balaiada no Maranhão, da Sabinada na Bahia e da Farroupilha no Rio Grande do Sul. De 1817 a 1850 , formou-se a ideologra e a corsciência possivel esteve às portas da consciência real, como em 1831, quando tremeu o Trono de D. Pedro. O Ato Adicional de 1834, com as facções congregadas, revelou-se instrumento insuficiente para descentralizar o império e manter os direitos que o Código de Processo Criminal de 1832 havia assegurado. Quem narra a históna dos malogros é Teófilo Otoni (1807-1869), que, discípulo de Cipriano Barata, fazendo renascer o Liberalismo, cede ao aulıcismo de uma cadeira senatorial em 64. " $O 7$ de Abril foi um verdadeiro journée des dupes. Projetado por homens de idéias liberais muito avançadas, jurado sobre $O$ sangue dos Canecas e dos Ratecliffs, $o$ movimento tinha por fim o estabelccimento dn governo cio puvo pelo povo por si mesmo, na significação mats lata da palavra." (Texto extraído da Circular, 19 set., 1860 , sem indicaçôes). $O$ acordo se fechara para salvar o princípıo monárquico. Explıca o autor da Circular o motivo de sua adesão aos moderados: " $E$ se a democracia criasse então uma oposição regular, eu não me chegaria provavelmente para os moderados. Porém a oposiçāo começou a revolver na corte e na Bahia os mais perigosos instintos da nossa sociedade, chamou em seu apoio a espada de soldados indisciplinados, quando se tratava da solução das mais graves questōes constitucionais. Órgão e defensor $d a$ democracia pacifica, o redator da Sentinela do Serro em tal contingência preferiu acostar-se ao principio monárquico, contanto que a monarquia fizesse por meio de reformas legais na constituição largas concessōes ao principio democrático". A inspiração seria republıcanızar a monarquia com teses de Jefferson, que o autor menciona. As reformas cogitariam de anular o Poder Moderador, abolir o senado vitalício e descentralızar, até a federação, o império. Os liberais temiam, na amplitude da alıança, os portadores dos "perigosos instintos da nossa sociedade". Os conservadores, os absolutistas e os moderados, se recompõem e, em poucos anos, freiam o "carro revolucionário". Seu sustentáculo será a Corte, consorciada ao comércio, acumpliciado com o tráfico. O liberal Teófilo Otoni, de seu lado, "nunca sonhou senão democracia pacifica, a democracia da 
classe média, a democracia da gravata. lavada, a democracia que com o mesmo asco repele o despotismo das turbas ou a tirania de um só. Ao passo que censurava os chefes do Partido Liberal Moderado, porque desvirtuavam a revolução, de que se haviam apoderado, a Sentinela do Serro com mais energia estigmatizava os excessos anárquicos aplaudidos pelas folhas democráticas da Corte. "A alıança com a "classe médıa" dependia de outro país, o país da propriedade parcelada, com empresas urbanas, um país que não exıst1a. Não for difícil, vencida a onda que se abre em 31 e abrange todo o espaço regencial, restaurar o conservadorismo, agora cristalizado num partido. Em pouco, as reformas da estrutura estatal, ainda que tímidas, foram cortadas e podadas pela reação centralizadora. As franquias do jún que asseguravam a justıça dos donos de terras e clientelas -, o direito de resistência, previsto no Códıgo Penal, a exposição do Poder Moderador, afastado o anteparo do Conselho de Estado, estas e outras garantias se amesquinhariam diante do poder oligárquico da Corte. Era o fim de um ciclo, com muitas jornadas de insubmıssão, nos sucessivos malogros de um pensamento que não conseguiu se realizar, casando-se à prátıca.

O Liberalismo teve uma base social definida, embora não-compacta. Não contou com a burguesia industrial, como o europeu, por ainda inexistente o industrialismo interno. A Revolução Industrial atuou, entretanto, de fora, impulsionando - aqui em 1deologia liberal atuante, sugerente - $\mathrm{o}$ Liberalısmo. Ele, ao contrário do modelo europeu, isolou-se dos "excessos anárquicos", das "turbas", dos "perigosos instintos de nossa sociedade", nas palavras de Teófilo Otonı. Conviveu com o escravismo, o que não o desajusta de seu arcabouço teónco, de acordo com o padrão mais persistente, o de Locke.
Ocorreu que, artıculado à descolonızação, não logrou organizar o Estado, por carência estrutural e pela deficiêncıa de uma consciência nacional real (PRADO JR., 1963, p. 187 - segs./SILVA DIAS, 1972, p. 165/COSTA, 1977 , p. 29 - segs./HOLANDA, 1970, t. II, v. 10, p. 29 - segs.). Este não será, entretanto, $o$ Liberalismo que a historiografia leva em conta. Há outro Liberalismo, com diversa fonte, que bem merece figurar entre aspas, havido como peculiar, especifico do Brasil.

Que é este Liberalismo, havido por específico no seu significado, que se expressa no século XIX? (COSTA, 1977, p. 1 10-1). Este não é o Liberalısmo como consciência possivel, vinculado à descolonızação, o de Cıprıano Barata e de Caneca. Este Liberalısmo é outro e provém de duas fontes, ambas com passagem pelo filtro oficial: a dos descolonizadores em compromisso, como Antônı Ca:los Rı́berro de Andrada, que, pretendem, sob o pálıo monárquico, com o aproveitamento da casa de Bragança, organızar uma transação, mantıda a supremacıa e a precedência do poder real. A outra fonte, a que dirıgirá os acontecimentos, a que atuará dentro da práxıs, como pensamento político, desvinculada da 1deologia e da filosofia política, sacrifica os valores liberais em favor da manutenção do Estado reformado. Será pela origem de seus executores e pela ênfase da obra, neopombalına. Seu momento de constitulção será o periodo que vai da Revolução Portuguesa de 1820 até a dıssolução da Assembléra Constituinte, em 12 de novembro de 1823. Ele - este tipo de Liberalismo se define na presença da Revolução de 1820 , tal como é assimilada pelas Cortes de D. João VI e D. Pedro I. Um ministro de D. João VI, S1lvestre Pinheıro Ferreıra (1769-1846), e um ministro de D. Pedro I, José Bonifácio de Andrada e Silva 


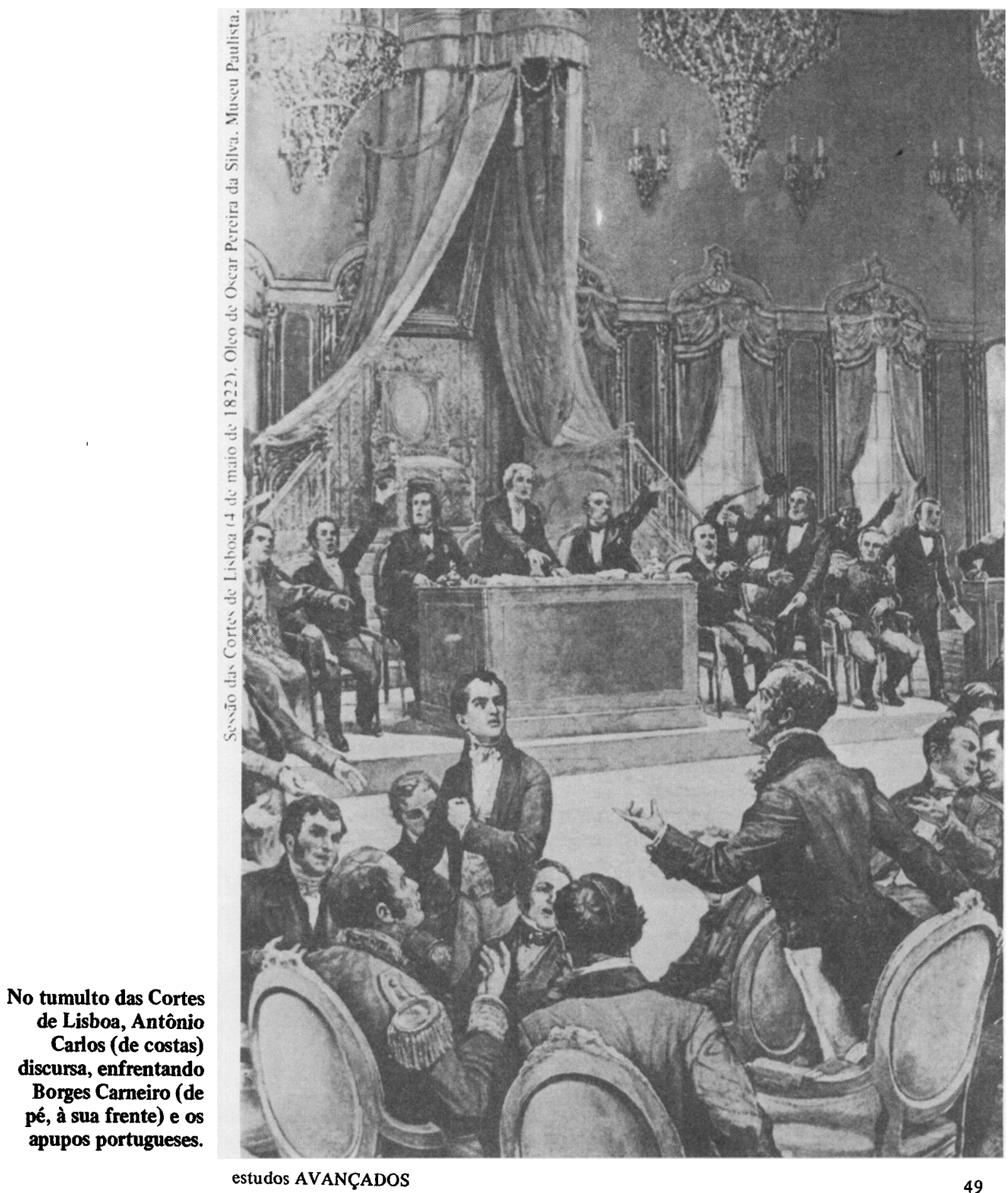


(1763-1838), serão os intérpretes do pensamento político dito liberal. Liberalismo que se esvazia para se cristalizar em constitucionalismo, na visáo de um, e de unidade nacional, na visão de outro. Para o último, José Bonifácio, o velho nativismo, o nacionalismo, que era antiportuguês no ataque à exploração comercial, se condensam numa obra do Estado. Para o outro, Silvestre Ferreira, todo o movimento dos novos tempos estaria na consagração de um estatuto, aında que nominal.

A Revolução Portuguesa de 1820 se inscreve no processo de atualızação ibérico com a Europa, tarda no século XIX e tarda no século XX. Ela reage contra o obscurantismo pós-pombalino, contra uma reforma interrompida, iluminada com a mudança social e política do continente. Ós exilados, entre os quais avulta, em Londres, Hipólito José da Costa (1774-1823), com o Correio Braziliense desde 1808, não se mostravam fascinados pelos princípios da Revolução Francesa. Eram, como os futuros revolucionários, vítımas da repressão, que pretendia segregar policialmente Portugal do mundo. Em 1820, o fascínio pelos abomináveis principios franceses estava atenuado pela invasão peninsular e pela restauração francesa, com a literatura que provocou em defesa da monarquia. " $E$ u um erro bem grande - dirá um copioso historiador dos acontecimentos - supor que devemos tudo à revolução francesa (.. .) o movimento intelectual iniciado pelo marquês de Pombal tem um caráter acentuadamente nacional, por isso mesmo que foi criàdo nas nossas necessidades e no nosso meio. As idéias propenderam mais para as teorias inglesas, cujas escolas tiveram mais aceitação dos sábios portugueses. Depois, os excessos da revolução francesa produziram em Portugal a mesma impressáo que na
Alemanha. Os revolucionários portugueses, como os alemães, procuraram legitimar as mudanfas politicas antes nas necessidades públicas e locais do que ras teorias francesas, cuja prática nōo foi das mais edificantes. (...) A cada momento que falam na necessidade de uma revolução, acrescentam logo que não a querem, como a da França, anárquica e sanguinária. Esta reação exagerada contra aquele país veio criar laços mais intimos entre as idéias portuguesas $e$ as dos sábios $e$ publicistas britânicos. "(D'ARRIAGA, 1886 , v. 1, p. 474-5.)

0 trio - liberdade, igualdade e fraternidade - não frequienta os escritos dos revolucionários e reformistas portugueses. $\mathrm{O}$ apoio maior do movimento português repousará sobre a burguesıa comercial, para a qual D. João VI, "mal se viu seguro no Brasil, começou a promover o desenvolvimento do novo império, à custa do negociante português, sobre cujas mercadorias lançou pesados impostos, enquanto abria os portos daquele pais a todas as naçōes" (D'ARRIAGA, 1886, v. 1, p. 586). Neste ponto, a Revolução Portuguesa, que se propagou no Brasil e aqui foi sustentada pelo exército português, mostrava sua face não-exportável. Os interesses dos produtores brasileiros eram adversos aos negociantes portugueses, cujo projeto chegaria, se vencedor, ao retorno da metrópole: o Liberalismo daqui era oposto ao Liberalismo de além-mar. Além da distância em que se situava a Revolução Portuguesa da Francesa, aberta quando estavam exaustos os impetos igualitários e libertários, o líder máximo, Manuel Fernandes Thomaz, invoca os precedentes pombalinos de sua formação coimbrã, quer vinculando o movimento à tradição das Cortes portuguesas, quer invocando 
Pombal sobre o problema do comércio de Portugal. Ele se propõe - e supõe que esse seja o escopo revolucionário completar a reforma pombalina (D'ARRIAGA, 1886, v. 20, p. 537-8; 572 - segs.). As tendências da burguesia comercial seriam mercantilıstas, num país desprovido de indústrias e com a agricul tura em abandono. As Cortes de Lisboa firmaram, antes da Constituıção, as Bases da Constituição, pelo decreto de 9 de março de 1821 , juradas no Brasil, o que abriu o espaço ao exercícıo dos dıreıtos ao debate polítıco, até então polıcıalmente impedido. Esta terá sido sua contribuição real ao Liberalismo brastleiro. Em Portugal, o pensamento liberal, posto que esboçado na Constıtuıção, que não chegou a vıger no Brasil, encontraria, depois de golpes e contragolpes, os seus fundamentos nas reformas de Mousinho da Silveira, que extirparam, na década de 30 , a agricultura do "parasitismo fidalgo e clerical" (SÉRGIO, 1972. p. 135). Depois dos acontecimentos de 1831 a 34, a história do Liberalismo em Portugal deixou de ser "uma comédia de mau gosto" (HERCULANO. s/d, t. II, p. 171). Multo esperaria o Reıno, entretanto, para completar, pela representação nacional, o edifício liberal.

A Revolução de 1820 , nas suas consequências sobre a Coroa, levou Silvestre Ferreıra ao minıstérıo de D. João VI. Seu nome distınguia-se fora do circulo cortesão, pelas preleções de filosofia, na sala do Real Colégio de São Francisco. Pertence, ao lado de José Bonifácio e Pereira da Fonseca, o futuro marquês de Maricá, à revista $\mathbf{O}$ Patriota. Procede do grupo que, desde Coimbra, adotara o pombalismo, sem retrair as reformas ao círculo traçado e inconformado con sua interrupção no reinado de $D$. Maria $I$, ao qual pertencera D. João, como regente. Convencido, depois da relutância inicial, de que deveria adequar-se à onda revolucionária portuguesa, com o risco da sobrevivência da Coroa, D. João VI socorre-se dos préstimos de Silvestre Ferreira, "não só um espirito de uma independência . fundamental e irreconciliável, como um reformador implacável, posto que manso, ao ponto de nāo raro parecer paradoxal e por vezes quimérico" (OLIVEIRA LIMA, 1945, v. 3, p. 1133).

Ele será, com suas dilações e suas concessões, o padrinho do "novo sistema representativo no Brasil". O impulso ganhara o exército e o clero, num impeto que aos espíritos da ordem parecia anárquico e aniquilador das prerrogativas régıas. $\mathbf{O}$ ministro cogitava - este o limite de seu reformismo - ficar "num caminho a igual distância dos desmandos revolucionários, que queriam reduzir a realeza a uma ficção, e das ilusões dos retrógrados, que julgavam possivel continuar a fazer pouco da revolução que rompera fremente na peninsula" (Idem, p. 1156). Ele aceita o Constitucionalısmo, havendo-o como sinônimo de Liberalismo, para organizar, na monarquia constitucional, o sistema representativo. Para que fosse liberal o sistema, digno do nome, deveria formar-se sobre um núcleo de direitos e garantıas individuais, constituindo a organızação dos poderes em promotores e defensores desses fundamentos, sob a garantia da representação nacional (JARDIN, 1985, p. III). Questionável é que se trate de Liberalismo - trata-se de uma reforma absolutista, com o caráter de liberalização. "O propósito de Silvestre Ferreira - é o que evidenciam seus escritos e sua ação - consiste sem divida em contribuir para que se completem as reformas iniciadas por Pombal, promovendo- a liberalização das instituiçōes politicas e, desta forma, completando o processo de inserção 
de Portugal na Epoca Moderma. Outro não era o ideal de parcela representativa da elite de seu tempo. "(PAIM, 1984, p. 272.)

$\mathrm{Na}$ súmula de suas idéras - segundo palavras suas - o exercício do poder legislativo, encarnado pelas Cortes, se faria com o "concurso e o consentimento do rei"'(FERREIRA, 1888, p. 277). A monarquia constitucional terra dois eixos: as Cortes, expressáo da vontade popular, e a aristocracia, composta de uma nobreza hereditárı, mas pelo mérito habilitada ao governo. A vontade popular - diria o liberalizante - se depuraria por um meio, "insıgnificante, mas único que existe": que "os homens menos espertos de cada povoação se louvem em outros mais instruidos nos interesses dos povos". (FERREIRA, 1888, p. 293).

Em momentos de crise, surge sempre uma voz que revela 1 que os atores escondem, velados na severa fisionomia da ação. $O$ conselheiro e espectador, que irrompe subitamente no Rio de Janeiro, neste ano de 1821 , scrá o conde de Palmela (Pedro de Sousa Holsteın, depois duque de, 1781-1850, com o recado inglês de ceder para não perder. Era 0 absolutista vestido de liberal, opinando que, antecipando-se às Cortes, D. João VI outorgasse uma carta constitucional. O cosmopolita e cétıco, oportunista e realista, trazia a lição de Luis XVIII, que aprendera nas Cortes européias, na convivência de Madame de Stat e Benjamin Constant. Se fosse possivel resistir, resistir-se-ia; em caso contrário, se transigiria, antecipando as reformas às que fossem exigidas. "Palmela tornou-se adeto do constitucionalismo saido da santa aliança, ou da liberdade, não inspirada na soberania nacional e nos interesses dos povos, mas da liberdade inspirada nos interesses das Coroas. . ."(D'ARRIAGA, 1886, v. 2, p. 425.)
E o Liberalismo como tática absolutista. Seu parecer, no qual aconselha a outorga de uma constituição, claramente explica o teor do Liberalısmo vigorante: " $E$, para me explicar melhor dızia a D. João VI -, direi que no meu conceito, vossa majestade tem duas coisas a fazer: a primeira é conceder 0 que já agora não pode negar; a segunda é impedir que essas concessões passem de certos limites, o que sem düvida acontcceria se se deixassem em Portugal os revolucionários legislar sem freio $e$ sem receio. $O$ primeiro objeto conseguiria vossa majestade por melo de uma carta constitucional que promulgasse; o segundo só poderia obter-se indo vossa majestade em pessoa, ou mandando o seu filho primogênito, para inspirar respeito e servir de centro aos bons portugueses. "(D'ARRIAGA, 1886 , v. 2, p. 313-4.)

Este, o esquema que será posto em marcha, ora como coluna principal, ora como expediente subsıdiánı no Constıtucionalısmo brasıleıro. Trata-se do modo comum de pensar, numa geração formada na atmosfera absolutista, arejada pelo Iluminsmo e as reformas pómbalınas.

A organızação do regime constitucional brasileiro não é conversível, ao contrário do que entendeu a historiografia brasileira, no Liberalismo. $O$ teor de suas idéias não ultrapassava o neopombalismo, tais como expressas por José Bonifácio. $O$ ponto de partida não é a carta de direitos, nem sequer a Constituição. No início de 22 , contra Ledo, Clemente Pereira e Januáno da Cunha Barbosa, explodia em palavras duras: "hei de dar um pontapé nestes revolucionários". "Hei de enforcar estes constitucionais na praça da Constituição" - eram ditos, ao tempo, a ele atribuídos. Seu projeto, na realidade, partia de outra base: a independência "moderada pela 
união nacional" (Obras Políticas de José Bonıfácio, 1973, v. 1, p. 271). Queria "um governo forte $e$ constitucional", forte porque constitucional, para desimpedir o "caminho para o aumento da crvilização e riqueza do Brasıl" (CALMON, 1972, p. 125) Pessoalmente, como percebeu com alegria o embaixador da Áustrua, não era "nem democrata, nem liberal" (SOUZA, 1972, t. 11, v. 3, p. 445). 0 centro de seu esquema de construção nacional será o Estado, no esquema pombalıno. "O Estado nacional brasıleiro nascia de uma tradıção absolutısta com uma forma liberal, para cooptar interesses econômicos divergentes, tais como o senhor rural e os do comerciante urbano "(BARRETO, 1977, p. 105 )

Hıpólito José da Costa, este con mais títulos de Liberalısmo do que José Bonıfácıo, receitava as reformas pela via do poder de cima para baixo. "Ninguém deseja mais do que nós as reformas útels, mas ninguém aborrece mais do que nós, que essas reformas sejam feitas pelo povo, pots conhecemos as más consequências desse modo de reformar, desejamos as reformas, mas feitas pelo governo, e urgimos que o governo as deve fazer enquanto é tempo, para que se evite serem fettas pelo povo. "( LIMA SOBR!, 1977, p. 79-80.)

A anomalıa desse Liberalısmo não era a convivêncıa com a escravıdão, mas a nota tônica do sistema constıtucional, colocada no Estado e não no indıvíduo, seus direitos e garantias (COSTA, 1977, p. 28) Os inconverientes do escravismo estavam presentes no espírito de losé Bonıfácio, como no de Hipólıto, sentidos que foram no próprio século XVIII, como atesta Vilhena. $O$ Liberalismo não é inconchliável com este escravismo. A partıcıpação popular no Lıberalısmo, ao contránio da democracia, excluı da cidadania não apenas o escravo, mas os setores negativamente privilegiados, aqui e na Europ̣a, sem escândalo ostensivo. A liberdade teria barreiras - como as tem no Liberalismo - ostensivas e profundas no horizonte inental do formulador da independência. Em tex to apresentado à Assembléia Constituinte, por ele escrito, Iıdo sob a responsabilıdade de D. Pedro, define o cerne de suas idéras, no fundo absolutistas, com o verniz liberalizante. Reclama dos deputados "uma constıtuição que, pondo barreiras inacessiveis ao despotismo, quer real, quer democrático, afugente a anarquia, e plante a árvore daquela liberdade, a cuja sombra deve crescer a união. tranquilidade e independência deste impérno. (. . .) Todas as constıtuições, que, à manetra de 1791 e 92, têm estabelecudo suas bases, e se tem quendo organizar, a expenência nos tem mostrado que são totalmente teoréticas, e metafísicas, e por isso inexequíveis, assim o prova a França, Espanha e ultımamente Portugal. Elas não têm feito, como deviam, a felicidade geral. mas sim, depois de uma licenciosa libcrdade, vemos que nuns paises já apareceu, e em outros ainda não tarda a aparecer o despotismo em um, depois de ter sido exercitado por muttos, sendo consequência necessária ficarem os povos reduzidos à triste situação de presenciarem e sofrerem todos os horrores da anarquia" (BONAVIDES e AMARAL VIEIRA, s/d, p. 100). Excluidos os modelos revolucionános da França, da Espanha e de Portugal, o que resta? Sobra o Constitucionalismo da restauração de Luis XVIII, uma vez que não se alude ao sıstema norte-amencano, rejeitado pelo conteúdo republicano.

O pensamento da restauração incumbe-se de separar o Liberalismo da democracia, unidos inicialmente pelo individualısmo. A conexão entre democracia e Liberalismo mostra sua face contrária. Conjurar a soberanıa do povo, ao mesmo tempo que proclama, define e organıza a liberdade, será o 
esforço de Benjamin Constant, Staël, Royer-Collard e Guizot (FAGUET, s/d, p. XV). Sua preocupação estará, nẫo em proteger a liberdade, mas, temendo a democracia, vigiá-la num equilíbrio de poderes, dos quais nenhum tem realmente origem popular. A bête noire será Rousseau. $\mathbf{O}$ inspirador, Benjamin Constant, com as brochuras que publica a partir de 1814, dogmaticamente aceitas. "Rousseau - diria Constant - amava todas as teorias da liberdade, mas forneceu o pretexto a todas as pretensōes da tirania." (CONSTANT, 1872, t. I, p. 128.)

A liberdade dos antigos, pelo seu teor participativo, continha o pengo de aniquilar os direitos invioláveis ao Estado. Só a liberdade moderna conseguiu estabelecer a barreira que os garantem. A nota tônica recai sobre o regime representativo, numa conciliação que leva em conta os poderes públicos, no fundo excluindo o "perigo" democrático (CONSTANT, 1872, t. II, p. 539-segs.). Esse Liberalismo, que já havia passado pela crítica dos conservadores, como Joseph de Maistre e De Bonald, emancipava-se da própria maioria, como instância legitimante (Idem, t. I, p. 278). 0 residuo, sobre o qual prospera o Liberalismo restaurado, será a organização do poder, limpo das impurezas despóticas, de um lado, e, de outro, com a recuperação da eficiência do poder; não apenas o instrumento capaz de evitar 0 arbítrio. $O$ caráter outrora meramente negativo do Liberalismo, numa vertente aberta desde Montesquieu, seria negado, em proveito de um mecanismo a organizar e a construir (HOLMES, 1984, p. 128). Por essa via entraria um quarto poder - o "poder neutro" - denominado na Carta de 1824 de Poder Moderador, caricaturado pelo absolutismo dos tradutores. Quanto ao povo, o limite era Montesquieu: liberdade do povo, não poder do povo.
A ossificação do modelo liberal, $o^{\prime}$ absolutismo mascarado de D. João VI e de D. Pedro I, pela voz de seus intérpretes, soldado ao Liberalismo restaurador, desçlassificou todas as concepções liberais autentıcamente liberass. 0 Constitucionalismo, que se apresentou como o sinônimo do Lberalismo, seguiu rumo específico, partıcularmente na Carta outorgada de 1824. O ciclo se fecha: 0 absolutismo reformista assume, com o rótulo, o Liberalismo vigente, oficial, o qual, em nome do Liberalısmo, desqualıficou os liberais. Os liberais do ciclo emancipador foram banıdos da históna das liberdades, qualificados de exaltados, de extremados, de quiméricos, teóricos e metafísicos.

Com a terminologia herdada da restauração - radicaux -, "os radicais foram expulsos da históna do pensamento politico" (COLOMBO, 1984). Seu liberalısmo for afastado, mas não superado, nem ultrapassou o estágio de consciência possivel. Que significará a exclusão, hoje irrecuperável, em virtude da mudança da estrutura, da sugerência que o tornou um dia necessáno?

\section{O Elo Perdido}

Um pensamento político sem Liberalismo, esta a conclusão? $\mathrm{Na}$ verdade, um pensamento político que o arredou, que vitoriosamente lutou para arredá-lo da vida nacional - o que não é a mesma coisa. A corrente banida, porque banida e não-inexistente, atua, ainda que subterraneamente, irrompendo na superfície em momentos de desajuste do sistema e de crise. Uma interrogação: qual a consequência atual do elo perdido? Hoje, com a mudança no campo histórico, seria impossível recuperar o tempo perdido, que ocuparia o espaço de um anacronismo. Como ideologia importada, de outro lado, teria atividade adjetiva, retórica, ornamental, sem
0 ciclo se fecha: 0 absolutismo reformista assume, com o rótulo, o Liberalismo vigente, oficial, o qual, em nome do Liberalismo, desqualificou os liberais. Os liberais do ciclo emancipador foram banidos da história das liberdades, qualificados de exaltados, de extremados, de quiméricos, teóricos e metafísicos. 
impacto sobre a dınâmıca política. A ıdéra sugere que o Liberalismo, uma vez superada a luta emancipacionista colonial, seria inútil, postiço, matéria morta no território das idéias políticas.

A realidade é outra. A ausência do Liberalısmo, que expressava uma dınâmıca dentro da realidade social $e$ econômica, estagnou o movimento politico, impedindo que, ao se desenvolver, abrigasse a emancipação. como classe, da indústria nacional. Seu impacto revelaria uma classe, retirando-a da névoa estamental na qual se enredou Interrompıda ficou, em consequência, a luta do produtor na crise do sistema colonial e do produtor quando a Revolução Industrial penetra no País. 0 Liberalismo, ao se desenvolver autenticamente, poderia, ao sair da crisálıda da consciência possivel, amplıar o campo democrático, que lhe é conexo, mas pode ser-lhe antagônıco. Por meio da representação nacional - que é necessána ao Liberalısmo - amplıa-se o territóno democrátıco, e particıpativo, conservando, ao süperar, o núcleo liberal. Chegar-se-ia a um ponto em que o que fosse democrático pressupusesse o espaço dos direitos e garantias liberais, ampliáveis socialmente, $O$ socialismo, numa fase mais recente, partiria de um patamar democrático, de base liberal, como valor permanente e não meramente instrumental. $\mathrm{O}$ quadro seria, em outra paisagem, o de nível curopeu, sem que uma reivindicação, por mínima que seja, abale toda a estrutura de poder. $O$ Estado seria outro, não o monstro patrimonial-estamental-autoritário que está vivo na realidade brasileira. Da uncongruência da dinâmica do pensamento politico, resultou que todas as fases suprimidas se recompõem como substitutos numa realidade absolutista, anda que reformista, ncopombalina em um momento, industrialista em outro, nunca com os olhos vol tados ao povo brasileiro, primeiro no respeito aos seus direitos, dcpois às suas reivındicações sociais. Com o salto, criou-se um monstro, tal como na imagem de Euclides da Cunha; o "Hércules Quasimodo"'. Quasimodo, se entende, pelo histórico aleijẫo. $O$ Hércules é a charada da fábula.

\section{Referências Bibliográficas}

ALBUQUERQUE, M. s/d. O poder polftico no Renascimento portugués. Lisboa,.Instituto Supcrior de Ciências Sociaıs c Polítıca Ultramarına. de Letras. 1974. A sombra de Maquiavel e a ética tradicional portuguesa. Lisboa, Faculdade

ANDRADE, A.A. 1946. Verney e a filosofia portuguesa. Braga, Liv. Cruz.

BARRETO, V. 1977. Ideologia e politica no pensamento de José Bonifácio de Andrada e Silva. Rio de Janciro, Zahar.

BESSA-LUIS, A. 1981. Sebastião José. Lisboa, Imprensa Nacional.

BOBBIO, N. 1977. Saggi sulla scienza politica in Italia. Editor Laterza.

BONAVIDES, P. e AMARAL VIEIRA, R.A. s/d. Textos politicos da História do Brasil. Fortaleza, Imprensa de Unıversidade.

BURNS, B. 1971. O llumıntsmo em duas bibliotecas do Brasil Colônta, Universitas, n. 8/9 sep.

CALMON, P., org. 1972. D. Pedro I. Proclamaçōes, cartas, artigas de imprensa. Ruo de Janeiro.

CARVAlHO E MELO, J. (Marquês de Pombal). 1861. Cartas e outras obras seletas do Marquez de Pombal. 5a ed., Lisboa, v. 2.

CASTElo bRANCO, C. s/d. Perfil do Marquês de Pombal. 7ạ ed., Porto Editora. 
CIDADE, H. s/d. Liçōes de cultura e literatura portuguesa. Coimbra, Coımbra Ed. COLOMBO, A. 1984. Radicalismo. In: BOBBIO, N. e MATEUCI, N. Dicionario de politica. CONSTANT, B. 1872. Cours de politique constıtutionnelle. Parıs, Librairie de Gullaumın. CORTESĀO, J. 1964. Os factores democráticos na formação de Portugal. Lisboa, Portugálıa Ed. 1966. Raposo Tavares e a formação territorial do Brasil. 'Lısboa, Portugálıa Ed., v. 1.

COSTA, E.V. 1977. Da República à Monarquia: momentos decısıvos. São Paulo, Grıjalbo.

D'ARRIAGA, J. 1886. História da revoluçāo portugueza de 1820. Porto, Liv. Portuense, v. $1,2,20$.

DERATHE, R. 1979. Jean-Jacques Rousseau et la science politique de son temps. Paris, J. Vrın.

DIAS TAVARES, L.H. 1959. Introdução ao estudo das idéuas do Movımento Revoluctonárto de 1798. Bahı, Liv. Progresso Editora.

DICKENS, A.G. 1969. La Contre-réforme. Parıs, Flammanion.

DUNN, J. 1984. Locke. Oxford University Press.

FAGUET, E. s/d. Poltiques et moralistes du dix-neuvième siécle. 9ạ ed., Parıs.

FALCON, F.J.C. 1982. A época pombalina. São Paulo, Ātıca.

FERREIRA, S. 1888. Cartas sobre a Revolução do Brasil. Revista do Instituto Histórıco. n. 51, 1.a parte.

FREI CANECA, J.A.D, 1979. Obras poltticas e literáras. Recife.

FRIEIRO, E. 1981. O diabo no livraria do cônego. Belo Horızonte, Itatıara.

GOLDMANN, L. 1972. A criação cultural na sociedade moderna. Lısboa, Presença.

GONZAGA, T.A. 1957. Tratado de direito natural. In O Obras Completas. Rio de Janeiro, Instituto Nacional do Livro, v. 2.

GOUGH, J.W. 1974. John Locke's political philosophy. Oxford, The Clarendon Press.

GRAMSCI, A. 1966. Concepção dialética da história. Rıo de Janeiro, Civılızação Brasıleura.

HALLEWELL, L. 1985. O livro no Brasil. São Paulo, T.A. Queiroz/Edusp.

HERCULANO, A. s/d. Opúsculos. 5a ed., Lisboa, Liv. Bertrand, v. 2.

HOLANDA, S.B. 1970. A herança colonıl: sua desagregação. In: civilizaçāo brasileira. São Paulo, Difusão Européı do Livro.

Históna geral da

1966. Apresentação. In: AZEREDO COUTINHO, J.J.C. Obras econômicas. São Paulo, Nacional.

HOLMES, S. 1984. Benjamin Constant and the making of modern liberalism. Yale University Press.

HUME, D. 1975. The history of England. Chicago, Unıversity of Chicago Press.

JARDIN, A. 1985. Histoire du libéralisme politique. Paris, Hachette.

KUHN, T.S. 1983. La structure des revolutions scientifiques. Par1s, Flammarion.

LACOMBE, A.J. 1970. A conjuração de Rio de Janeiro - 1794. In: HOLANDA, S.B., org.

História geral da civilização brasileira. São Paulo, Difusâo Europé1a do Lıvro, v. 20.

La république. L, VI, 484. Plé1ade, v. I.

. Les lois, 962.

LEITE, S.J. 1965. Suma histórica da Companhia de Jesus no Brasil. Lısboa, Junta de Investıgação de Ultramar.

LIMA SOBRo, B. 1977. Antologia do Correio Braziliense. Rio de Janeıro, Cátedra-MEC.

LOCKE, J. 1952. Civil government. The Great Books.

LUKÄCS, G. 1960. Histoire et consctence de classe. Paris, Les Editions de Minuit.

MAGALHÃES, J.C. 1967. História do pensamento politico em Portugal. Coumbra, Coimbra Ed. 
MARINHO, J.A. 1977. Históna do movimento politzco de 1842. USP-Itatia1a.

MARX, K. 1968. Crittca de la filosofia del derecho de Hegel. Buenos Aires, Ed. Nuevas.

MARX, K. e ENGELS, F. 1959. La ıdeologia alemana. Montevideo, Ed. Pueblos Unidos.

MAXWELL, K.R. 1973. Conflict and conspiractes Brazll and Portugal 1750-1808. Cambridge, Cambridge University Press.

MELLO, E.C. 1986. Rubro veio. R10, Nova Fronteura.

MELLO E SOUZA, A.C. 1981. Formação da literatura brasilezra. Belo Horıonte, Itatiaı, v. 1. MESNARD, P. 1977. L'essor de la philosophe politique au XVI siécle. Parı, Liv. J. Vrın.

MONCADA, C. 1949 Estudos de história do diretto. Coimbra, Universıdade de Coimbra, v. 2.

MONTENEGRO, J.A.S. 1978. O liberalısmo radical de Frei Caneca. Rio de Janeiro, Tempo Brasileiro.

MOTA, C.G. 1979. Idéia de revolução no Brasıl (1 789-1801). Petrópolı, Vozes 1972. Nordeste 1817. São Paulo, USP-Perspectiva.

MUNIZ TAVARES, F. 191 7. História da revoluçāo de Pernambuco de 1817. Recife, Imprensa Oficial.

NOVAIS, F.A. 1985. Portugal e Brasıl na crise do antıgo sistema colonual (1777-1808). São Paulo, Hucitec.

OAKESHOTT, M. 1978. Experience and its modes. Cambridge, The University Press. 1984. Rationalism in polttics and other essays. Londres e Nova lorque, Methuen.

Obras polítıcas de José Bonifácıo. Senado Federal, 1973. v. 1.

OLIVEIRA LIMA, M. 1945. Dom Joâo VI no Brasil. Rıo, José Olımpıo, v. 3.

1947. O movimento da independéncta. O Império brasiletro (1821-1889). 2a ed., São Paulo, Mclhoramentos.

1975. Pernambuco seu desenvolvimento histónico. Recife.

OLIVEIRA MARTINS, J P. c PEREIRA, A.M. 1942. História de Portugal. Lisboa.

PAIM, A 1984. Históna das ıdélas filosóficas no Brasil. São Paulo, Ed. Convívio.

PINTO NEVES, M.C. 1985. Teoria do Dtretto, inconstıtuctonalidade das lets e semiónca. Recife, (Tese de mestrado mimcografada).

PLATÃO. Théetète. In 'Oeuvres complètes. Plérade, v. II.

PRADO JR., C. 1963. Evolução Polítıca do Brasıl. São Paulo, Brasıliense.

PRELOT, M. 1966. Histoire des idées politiques. Par1s, Dalloz.

QUEIROS MATTOSO, K.M. 1969 Presença francesa no movtmento democrático baiano de 1798. Bahıa, Itapuã.

REBLLO, L.S. 1983. A concep̧̧̃̃o do poder em Fernão Lopes. Livros Horizonte.

REGO, R., org. s/d. O processo de Damtão de Góes na Inquisıção. Lisboa, Ediçōes Excelsıor.

RITTER, G. 1964. Ursprung und Wesen der Menschenrechte. In Zur Geschichte der Erklärung der Menschenrechte. Darmstadt, Wissenschaftliche Buchgesellschaft.

RODRIGUEZ PANIAGUA, J.M. 1984. Historia del pensamiento juridico. Madri, Universıdad Complutense.

SAINT HILLAIRE, A. 1938. Segunda viagem do Rıo de Janetro a Minas Gerats e a São Paulo 1922. s/l, Brasiliana, v. 126, 126a.

SARAIVA, A.J. e LOPES, 0. 1968. Históna da literatura portuguesa. 2a ed., Porto Edıtora.

SCHWARTZ, R. 1977. Ao vencedor as batatas. São Paulo, Duas Cidades.

SÉRGIO, A. 1924. Antologia dos economistas portugueses. Lisboa.

estudos AVANÇADOS 
SICHES, L.R. 1965. Tratado general de Filosofia del Derecho. 3a ed., México, Editorial Porrua.

SILVA DIAS, M.O. 1972. A interiorização da metrópole (1808-1853). In: MOTA, C.G. 1822.

Dimensōes. São Paulo, Perspectiva.

SKINNER, Q. 1979. The foundations of modern political thought. Cambridge, Cambridge

University Press, v. 1, 2.

SOUTHEY, R. 1965. História do Brasil. São Paulo, Ed. Obelisco, v. 6.

SOUZA, O.T. 1972. A vida de D. Pedro I. História dos fundadores do Império do Brasil. v. 3.

STRAUSS, L. e CROPSEY, J. 1973. History of political philosophy. 2a ed., Chicago, University of Chicago Press.

TOCQUEVILLE, A. 1952. L'ancien regime et la révolution. Paris, Gallimard.

VARNHAGEN. 1956. História geral do Brasil. São Paulo, Melhoramentos, v. 5.

VILAR DE CARVALHO, G. 1980. A liderança do clero nas revoluçôes republicanas de 181 7-1824. Petrópolis, Vozes.

VILHENA, L.S. 1969. A Bahia no século XVIII. Bahı, Ed. Itapuã, v. 1,3.

WOLIN, S. 1960. Politics and vision. London.

\section{Bibliografia}

BRAGA, T. História do diretto português. Os Forais. Coımbra, Ed. da Unıversıdade, 1868.

HERCULANO, A. Opúsculos. 5. ed., Lisboa, Livrarıa Bertrand, s/d. t. II, v. 2.

QUENTAL, A. Causa da decadêncıa dos povos peninsulares nos últımos três séculos. In: Prosas.

Coimbra, Ed. da Universidade, 1926.

SILVA, R. D. João II e a nobreza. Lisboa, 1910.

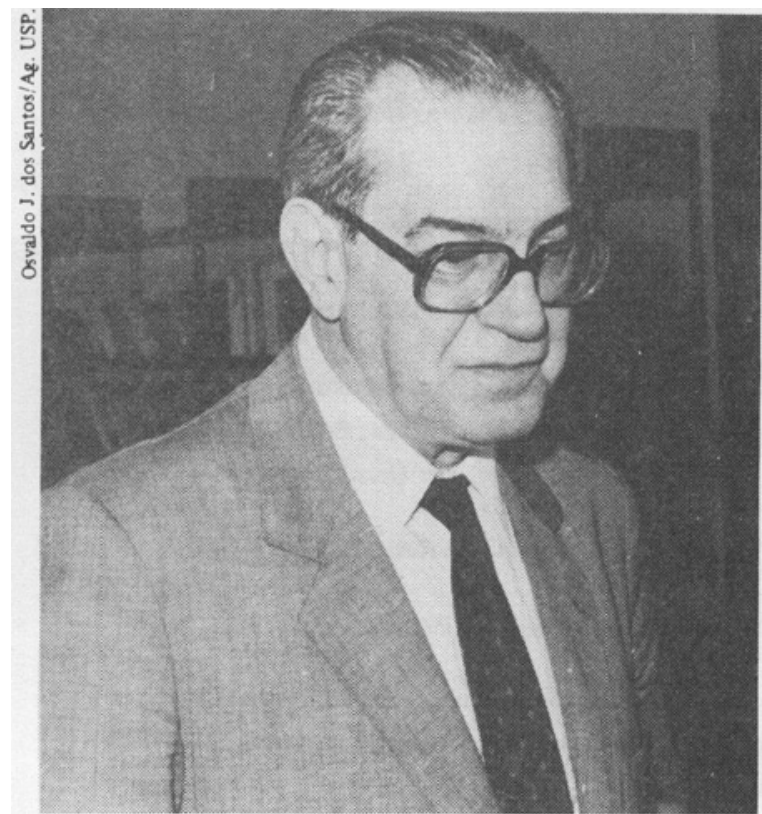

\section{Raymundo Faoro}

Raymundo Faoro, 62, é neto de imigrantes italianos, nascido em Vacaria (Rio Grande do Sul), jurısta, socıólogo, historiador e cientısta político, lançou, em 1958, a primeira edição de Os Donos do Poder, obra que o consagrou como um dos grandes pensadores da realidade brasileira. Em 1975, publicou Machado de Assis: a pirâmide e o trapézio (atualmente na $3^{a}$ edıção e, da meśma forma que a anterior, pela Editora Globo), uma interpretaçāo histórico-sociológica do universo ficcional de Machado de Assis. Em 1977, derrotou o senador Josephat Marinho na eleıção para a presidência do Conselho Federal da Ordem dos Advogados do Brasil, cargo que ocupou até março de 1979, desempenhando um papel decisivo na derrocada do regime militar. Em 1981, elaborou as primeiras teses sobre os meios de se convocar uma Assembléia Nacional Constituinte soberana e democrática, reunidas no livro Assembléia Constituinte - a legitimidade recuperada. Colaborador regular da Revista Senhor, participou semanalmente também na Revista IstoÉ e cotıdianamente no Jornal da República, e vem publicando, há muitos anos, artigos assinados em vários outros órgãos de imprensa. Raymundo Faoro foi o primeiro professor-visitante do Instituto de Estudos Avançados da USP, durante o segundo semestre de 1986, onde, além de desenvolver projeto de pesquisa e interagir com a comunidade acadêmica, ajudou a definir a filosofia e o estılo de trabalho do IEA.

$$
\text { estudos AVANÇADOS }
$$

